\title{
Taxonomy, distribution and new taxa from the Habenaria crucifera (section Nudae, Orchidaceae) aggregate from Brazil and the Guianas
}

\author{
João A. N. Batista ${ }^{1}$ and Luciano de Bem Bianchettio ${ }^{2}$ \\ ${ }^{1}$ Departamento de Botânica, Universidade Federal de Minas Gerais, Av. Antônio Carlos 6627, \\ Pampulha, C.P. 486, Belo Horizonte, MG 31270-910, Brazil; e-mail: janb@icb.ufmg.br \\ ${ }^{2}$ Embrapa Recursos Genéticos e Biotecnologia, Parque Estação Biológica, Final Av. W5 Norte, \\ C.P. 02372, Brasília, DF 70770-901, Brazil; e-mail: bianchet@cenargen.embrapa.br
}

\begin{abstract}
The taxonomy, morphology, and geographic distributions of Habenaria crucifera and related species in section Nudae were investigated. Habenaria galeandriformis and $H$. montiswilhelminae are included in the affinity of $H$. crucifera and four new taxa are described: H. cardiostigmatica, H. crucifera var. brevidactyla, H. guaraensis, and H. spanophytica. These species form a subgroup within section Nudae, characterized by linear grass-like leaves that are appressed to the stem; green flowers; simple or discretely bipartite petals; a tripartite lip; a rostellum midlobe completely placed between the two anther loci; stigma lobes that are closely parallel; and a separated hemipollinarium. This group of species ranges from the Guianas to the state of Rio Grande do Sul in southern Brazil, but is concentrated in the cerrado of central Brazil. Diagnostic characters, illustrations, descriptions and notes on the habitat, distribution, phenology, and conservation status are presented for all species here recognized.
\end{abstract}

Key Words: Conservation status, Neotropics, Orchidinae, species delimitation, systematic, tropical grasslands.

Resumo. A taxonomia, morfologia e distribuição geográfica de Habenaria crucifera e espécies relacionada na seção Nudae foi investigada. Habenaria galeandriformis e $H$. montiswilhelminae são incluídas na afinidade de $H$. crucifera e quatro táxons novos são descritos: H. cardiostigmatica, $\mathbf{H}$. crucifera var. brevidactyla, $H$. guaraensis e H. spanophytica. Essas espécies formam um subgrupo da seção Nudae caracterizado pelas folhas graminóides, lineares, apressas ao caule, flores verdes, pétala simples ou discretamente bipartida, labelo tripartido, lobo mediano do rostelo completamente compreendido entre os lóculos da antera, lobos do estigma próximos, paralelos, e hemipolinários separados. A distribuição das espécies estende-se das Guianas até o estado do Rio Grande do Sul no sul do Brasil, mas concentra-se no cerrado do Brasil central. Caracteres diagnósticos, ilustrações, descrição e comentários sobre o habitat, distribuição, fenologia e status de conservação são apresentados para cada espécie.

Habenaria (Habenariinae, Orchideae, Orchidaceae) is a large genus of about 600 terrestrial species distributed through the tropical and subtropical regions of the Old and New Worlds (Pridgeon et al., 2001). The main centers of diversity of the genus are in
Brazil, southern and central Africa, and East Asia (Kurzweil \& Weber, 1992). Brazil, with 165-170 species (Hoehne, 1940; Pabst \& Dungs, 1975), is the country with the largest number of Habenaria species in the New World and possibly also worldwide. Habena- 
ria is also the largest orchid genus in Brazil. The main centers of diversity of the genus in Brazil are the cerrado, a species-rich savanna vegetation covering about 2 million $\mathrm{km}^{2}$ of Central Brazil (Ratter et al., 1997), and the campos rupestres (rocky fields) of the central and southeastern regions. The Federal District $\left(5783 \mathrm{~km}^{2}\right)$ alone, located in the central region of the cerrado and the administrative region of the Brazilian capital, bears 77 taxa of Habenaria (Batista \& Bianchetti, 2003).

The only worldwide revisions of Habenaria were those of Kraenzlin $(1892,1901)$, in which 32 sections were recognized. Characterization of the sections was based primarily on the degree of dissection of the petals and lip, and on column structure, particularly the length of the stigma lobes. Cogniaux (1893), in his treatment of Habenaria in Flora Brasiliensis, followed Kraenzlin's sectional characterization in general lines. Unfortunately, the treatments presented by Kraenzlin and Cogniaux for the neotropical sections are clearly artificial. Consequently, most of the sections have unrelated taxa, and closely related species are dispersed among different sections. Despite the problems in the infrageneric classification, among the Habenaria species from Brazil some distinct groups of species are recognizable, including the species assigned to sect. Macroceratitae Kraenzl. (Batista et al., 2006), and the informal species-groups centered around $H$. parviflora Lindl., H. repens Nutt., H. nuda Lindl. and $H$. secunda Lindl., among others.

Section Nudae was created by Cogniaux (1893) as a substitute for section Sartores Kraenzl. As defined by Cogniaux, sect. Nudae comprises 13 species from Brazil, including $H$. aphylla Barb. Rodr. In the course of a survey of the orchid flora of the cerrado of central Brazil, the examination of dry and living specimens revealed several distinct taxa that were previously identified as $H$. aphylla, now a synonym of $H$. crucifera Rchb.f. \& Warm. Additionally, an examination of the Habenaria species from Brazil and neighboring countries revealed two more species similar to $H$. crucifera. As a contribution to the taxonomy of the genus Habenaria in Brazil and the Neotropics, an investigation on the taxonomy, morphology and geographical distribution of $H$. crucifera and related species is presented here.

\section{Material and methods}

The study was based on field collections made by the authors and on the examination of dried specimens from the following herbaria: AMES, BHCB, CEN, HB, HEPH, IBGE, ICN, MBM, MG, NY, OUPR, P, RB, SP, SPF, U, UB, and W. All cited specimens were seen by the authors, except otherwise indicated. The identifications were made by comparison with the original descriptions and, when available, with the type material or photographs of types. The main taxonomic works referred were those of Barbosa Rodrigues (1877), Reichenbach (1881), Kraenzlin (1892), Cogniaux (1893), Hoehne (1937), and Renz (1992). All descriptions were based on the pickled or the herbarium material examined. Details of the flowers, particularly column structure, were examined under a stereoscopic microscope. Data on flowering times, habitats and distribution were based on herbarium labels of the collections examined, or on field studies. Reports from the literature that could not be confirmed in the material studied were not included. Habit, perianth and ovary + pedicel were drawn from dried material, while flower, column and rostellum were drawn from pickled material, except in Fig. 7H, which was drawn from dried material. All illustrations were made from mature flowers, except $\mathrm{G}$ and J, in Fig. 1, which were drawn from a flower bud. Abbreviations for the Brazilian states are as follows: BA, Bahia; GO, Goiás; MG, Minas Gerais; SP, São Paulo, and DF, Distrito Federal.

\section{Taxonomy and descriptions}

Habenaria crucifera was described in 1881 by Reichenbach filius based on a collection made by Eugen Warming in Lagoa Santa, Minas Gerais, Brazil. Kraenzlin (1892) placed the species in sect. Sartores Kraenzl. Cogniaux (1893) considered H. crucifera a synonym of $H$. aphylla Barb. Rodr., transferred it to sect. Nudae Cogn. and was followed by all further authors including Hoehne (1940) and Pabst and Dungs (1975). However, $H$. aphylla Barb. Rodr. is a latter homonym of Habenaria aphylla (Forskahl) R.Br. A critical examination of the original descriptions, illustrations, and type images of $H$. aphylla Barb. Rodr. and H. crucifera confirms Cogniaux's (1893) statement that the two species are 


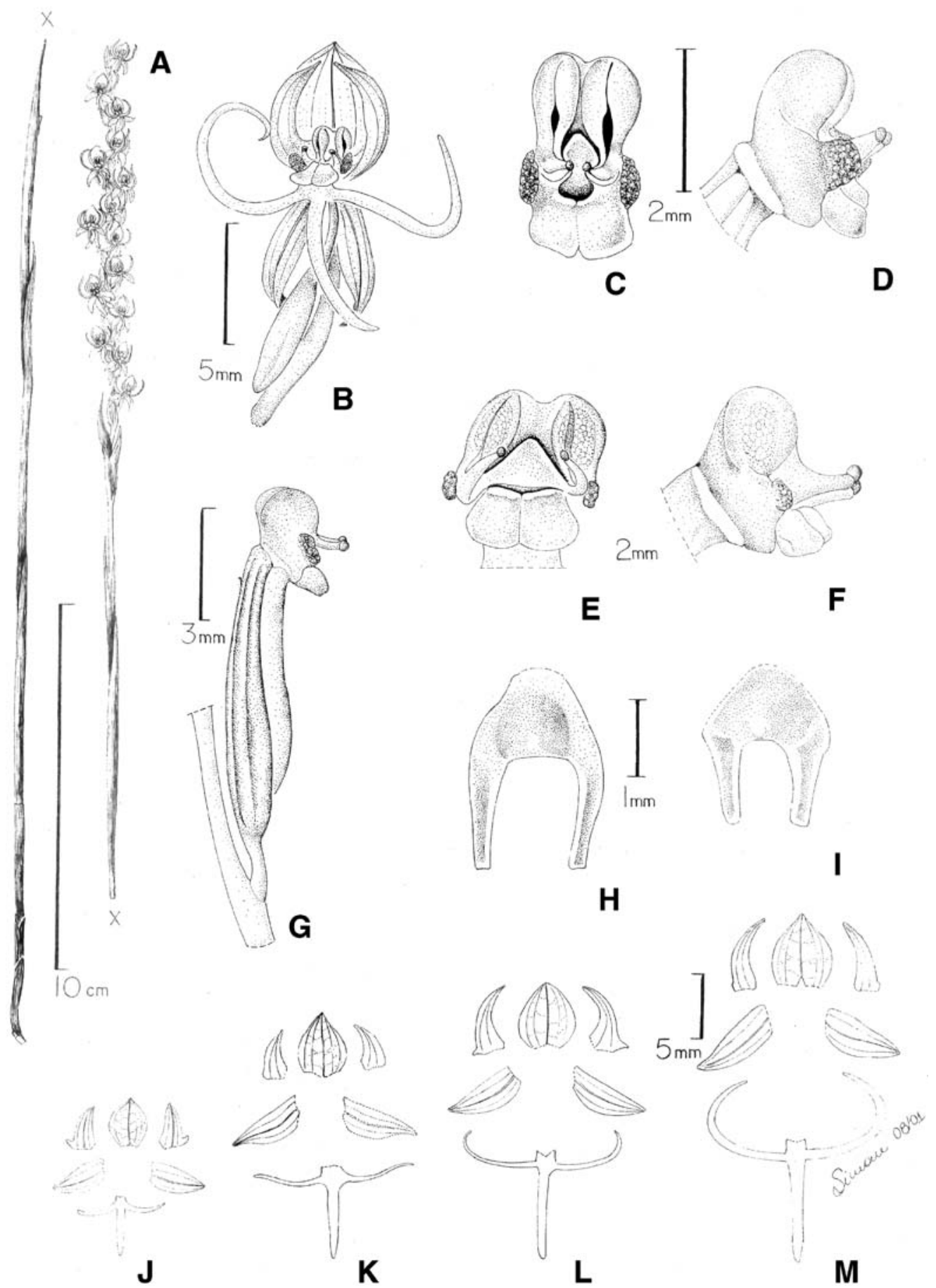

Fig. 1. Habenaria crucifera var. crucifera. A. Habit (Bianchetti \& Batista 825, CEN). B. Flower, front view. C. Column, front view. D. Column, lateral view (B-D, Batista \& Lemos 1069, CEN). E. Column, front view. F. Column, lateral view (E-F, Batista 478, CEN). G. Pedicel, ovary, column and spur, side view (Warming s.n., AMES). H. Rostellum, upper view (Batista 478, CEN). I. Rostellum, upper view (Batista \& Lemos 1069, CEN). J. Perianth (Warming s.n., AMES). K. Perianth (Hoehne s.n., SPF 11072). L. Perianth (Hatschbach et al. 64239, MBM). M. Perianth (Batista \& Lemos 1069, CEN). 
conspecific but, H. crucifera is recognized here as the accepted name for the species.

Habenaria galeandriformis Hoehne and $H$. montiswilhelminae Renz, and four new taxa described here $(H$. cardiostigmatica, H. crucifera var. brevidactyla, $H$. guaraensis, and $H$. spanophytica) are similar to $H$. crucifera and together they form a distinct subgroup within sect. Nudae. This subgroup can be characterized by leaves that are linear, narrow, grass-like, and mostly appressed to the stem, giving to the plant a leafless aspect. In addition, the flowers are small (dorsal sepal shorter than $5 \mathrm{~mm}$ ) to medium sized (dorsal sepal 6-12 mm long), and mainly green, with petals that are simple or discretely bipartite, with the anterior segment short and reduced to a tooth-like projection, a tripartite lip, and lateral segments that are less than half the length of the median segment to 1.6 times as long as the median segment. The rostellum midlobe is completely placed between the two anther loci, with the side-lobes parallel (rarely convergent), the stigma lobes are convex, turned forwards, and closely parallel, and the hemipollinarium is separated.

Two additional species are similar to the species treated here but were not included due to differences in the morphology of the flowers. Habenaria pungens Cogn., from central Brazil and Bolivia, also has linear leaves that are appressed to the stem, and small flowers and short lateral segments of the petals and lip, but its flowers are bright yellow, nonresupinate, and the inflorescence is congested, and umbel-like. Habenaria rotundiloba Pabst, from northeastern Brazil, has rounded lateral segments of the lip, a unique characteristic among the New World species, and its affinities within the genus are unclear.

\section{Key to the species of the $\boldsymbol{H}$. crucifera aggregate}

1. Lateral segments of the lip less than half the length of the median segment.

2. Stem 97-130 cm long, including the inflorescence; ovary+pedicel 9-12 mm long; dorsal sepal 4-4.5 $\times 3.5-4 \mathrm{~mm}$; column 2.5-3 mm high; anther canals $0.8 \mathrm{~mm}$ long; rostellum ca. $2 \mathrm{~mm}$ long .......................... H. galeandriformis

2. Stem 36-108 cm long, including the inflorescence; ovary + pedicel (10-)13-20 mm long; dorsal sepal (4-)6-9(-12)× (4-)5.5-7(-9) mm; column 4-4.5 mm high; anther canals $1.3-2 \mathrm{~mm}$; rostellum $2.7-3 \mathrm{~mm}$ long

1. Lateral segments of the lip more than half the length of the median segment

3. Lateral segments of the lip $1 / 2$ to $3 / 4$ the length of the median segment; spur $4.5-5 \mathrm{~mm}$ long

H. crucifera var. brevidactyla

3. Lateral segments of the lip slightly shorter, the same length or up to 1.6 times as long as the median segment; spur 6-10.5 mm long.

4. Dorsal sepal 5-6(-7) mm long.

5. Plants from seasonally humid or dry fields; lateral segments of the lip erect or perpendicular to the median segment, perpendicular or forming a obtuse angle with the median segment, the same size to 1.5 times as long as the median segment; auricles $0.61 \times 0.7-0.8 \mathrm{~mm}$, not covering the anther canals or rostellum sidelobes ................................................................................ H. crucifera var. crucifera

5. Plants from permanently wet fields; lateral segments of the lip deflexed, forming an acute angle with the median segment, slightly shorter to the same length as the median segment; auricles $1.3 \times 1.5-1.8 \mathrm{~mm}$, laterally covering the anther canals and rostellum side-lobes ............................................................ H. guaraensis

4. Dorsal sepal (2.5-)3-4(-4.5) $\mathrm{mm}$ long.

6. Dorsal sepal 3.5-4(-4.5) $\mathrm{mm}$ long; space between the stigma lobes heart-shaped; rostellum side lobes parallel throughout; viscidia spaced $0.7 \mathrm{~mm}$ apart ...................................... . cardiostigmatica

6. Dorsal sepal (2.5-)3 mm long; space between the stigma lobes circular; rostellum side lobes convergent towards the apex; viscidia very close to one another, up to $0.2 \mathrm{~mm}$ apart ............................. H. spanophytica

Habenaria crucifera Rchb.f. \& Warm. var. crucifera, Otia Bot. Hamb. 2: 80. 1881. Type: Brazil. Minas Gerais: Lagoa Santa, $J$. E. B. Warming 142 (holotype: W, image seen).

(Figs. 1, 2)
Habenaria aphylla Barb. Rodr., Gen. Sp. Orchid. 1: 158. 1877, nomen illegit., non Habenaria aphylla (Forskahl) R.Br., Prodr. 1: 312. 1810. Type: Brazil. Minas Gerais: Serra do Tamanduá, J. Barbosa Rodrigues s.n. (holotype: unknown, presumably lost; original illustration by Barbosa Rodrigues in Icon- 
ographie des Orchidées du Brésil, vol. 1, t. 11A: RB, copy K; reproduced in Sprunger, 1996: 1: 64A).

Terrestrial herbs. Stem erect, (19-)30$66 \mathrm{~cm}$ long, including the inflorescence, 1$2.5 \mathrm{~mm}$ wide. Leaves $6-11$, appressed to the stem, largest at the center of the stem, linear, narrow, 4-12×0.4-0.7 cm. Inflorescence (4-) $8-16(-22) \mathrm{cm}$ long, few to many flowered; bracts ovate, $7-30 \times 4-6 \mathrm{~mm}$, caudate, about the same size as the ovary+ pedicel. Flowers (4-) 7-18(-26), medium sized, greenish; ovary + pedicel 9-14 mm long, slightly arched. Sepals green, main veins slightly marked in darker green, discretely mucronate, margin smooth, whitish; dorsal sepal concave, when flattened ovate or roundish, 5-6(-7) $\times 4-5.5 \mathrm{~mm}$; lateral sepals obliquely ovate to ovate-lanceolate, deflexed, 5.5-8 $\times(2-) 2.5-3 \mathrm{~mm}$. Petals discretely bipartite, base whitish, turning light green towards the segments apices; posterior segment oblong-lanceolate, falcate, 4.5-6×1$1.5(-2) \mathrm{mm}$, acute, connivent with the dorsal sepal; anterior segment reduced to a tooth-like projection, inserted at the base of the posterior segment, $0.5-0.8(-1) \mathrm{mm}$ long, apex usually truncate. Lip distinctly tripartite, base whitish, turning light green towards the segments apices; undivided basal part short, $1(-1.5) \times 1-$ $1.3 \mathrm{~mm}$; side segments erect or perpendicular to the median segment, linear-filiform, (6-)7.5-10 (-12) $\mathrm{mm}$ long, the base perpendicular or forming a obtuse angle with the median segment; median segment linear, geniculate, 5.5$8.5(-10) \times 0.8-1 \mathrm{~mm}$. Spur pending, totally or partially covered by the bracts, usually slightly flexuose, clavate, shorter than the ovary+ pedicel, 6-10 $\mathrm{mm}$ long, green, base $0.7-1 \mathrm{~mm}$ wide, apex 1.5-2(-2.5) $\mathrm{mm}$ wide. Column erect, $3 \mathrm{~mm}$ high; connective emarginate, green; auricles fleshy, verrucose, whitish, 0.6$1 \times 0.7-0.8 \mathrm{~mm}$, not covering or slightly covering the anther canals and rostellum side-lobes. Anther 1.7-1.8 mm high, canals $1-1.3 \mathrm{~mm}$ long; hemipollinarium separated; viscidia $0.2-$ $0.3 \times 0.2 \mathrm{~mm}, 1.2-1.5 \mathrm{~mm}$ apart from one another; caudicles $1.3-1.5 \mathrm{~mm}$ long; pollinia $1.3-1.5 \times 0.8 \mathrm{~mm}$. Stigma lobes $2-2.3 \mathrm{~mm}$ long, green, receptive surface convex, turned forwards, closely parallel, free part 1.2-1.3× $1 \mathrm{~mm}$, apex truncate, inner margin thickened, space between the stigma lobes circular. Rostellum 2.2-3 $\mathrm{mm}$ long, greenish; midlobe triangular, fleshy, acute, completely placed between the anther loci, 1-1.3 $\mathrm{mm}$ long, $1 \mathrm{~mm}$ high, side-lobes parallel throughout, $1.2-1.8 \times 0.2-0.3 \mathrm{~mm}$.

Distribution.- In grasslands of central, southeastern and northeastern Brazil, in the states of Bahia, Minas Gerais, São Paulo, and the Federal District (Fig. 3). Cogniaux (1906) and Pabst (1971) have reported the species for Goiás, but we have not seen material from this state.

Habitat, ecology, and phenology--Habenaria crucifera grows in dry and seasonally humid grassy fields, usually over deep, gray, sandyclay soil, and is frequently associated with murundus. The soil in these areas can be superficially humid during the rainy season but dries completely during the dry season. Other Habenaria species such as $H$. alpestris Cogn., H. heringeri Pabst, H. juruenensis Hoehne, H. secundiflora Barb. Rodr. and other orchid species such as Veyretia simplex (Griseb.) Szlach., Galeandra styllomisantha (Vell.) Hoehne and Lyroglossa grisebachii (Cogn.) Schltr. occur in the same habitats, blooming at approximately the same time. In central Brazil flowering occurs from the beginning to near the end of the rainy season, from late November to March (Table I). Brushfires during the dry season greatly stimulate the bloom of the species. Eleven out of the 13 collections of the species made by the authors were made in previously burned areas.

Conservation status. - The use of the World Conservation Union Red List Categories and Criteria (IUCN, 2001) for seasonal terrestrial species with inconspicuous leaves is difficult, particularly in regard to the estimation of population sizes. Plants of $H$. crucifera and related species can only be observed during flowering time and individuals without flowers are almost impossible to detect and count mixed with the grassy vegetation. In all collections of the species made by the authors, about no more than 10-20 flowering individuals were seen for each population. In some occasions, a single or few specimens in flower were observed. Nevertheless, considering the broad distribution of the species and the unlikelihood of any collection pressure, the species can tentatively be classified as Least Concern. However, loss of habitat is a real threat, as the seasonal humid fields favored by the species are 

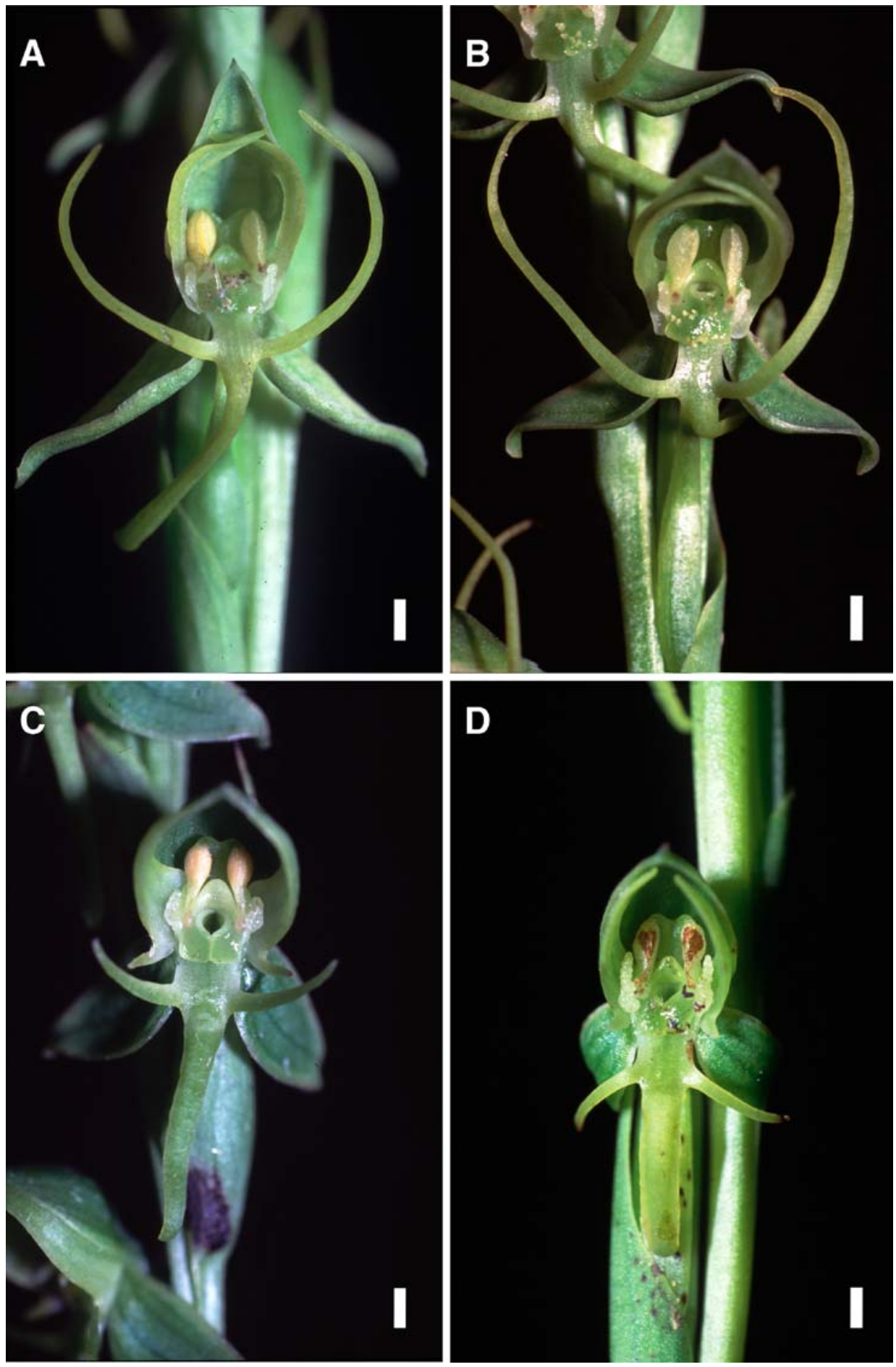

Fig. 2. Flowers from live specimens. Habenaria crucifera var. crucifera. A. From Poço Azul, Chapada da Contagem, Federal District. B. From Três Barras stream, Brasília National Park, Federal District. H. crucifera var. brevidactyla. C. From 'Reserva Ecológica do Guará', Federal District. H. guaraensis. D. From 'Reserva Ecológica do Guará', Federal District. Scale bars $=1 \mathrm{~mm}$. 


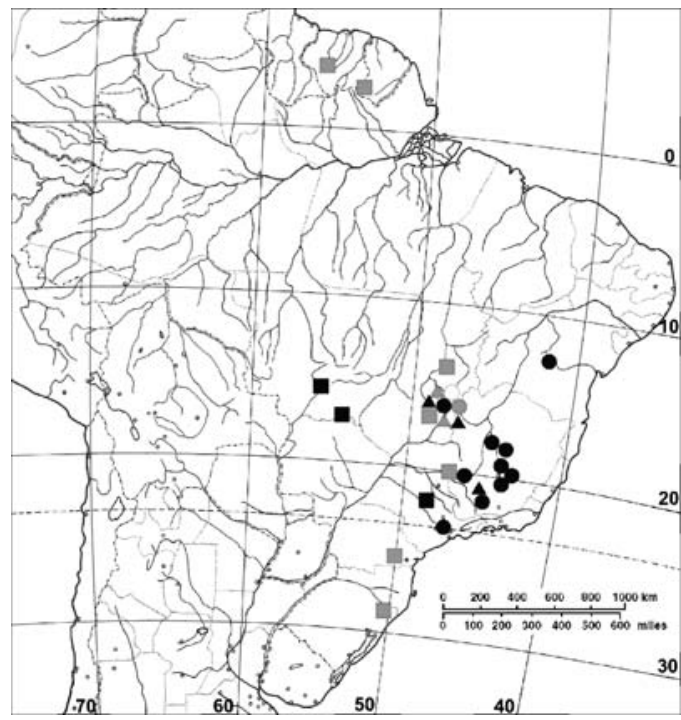

Fig. 3. Distributions of Habenaria crucifera var. crucifera (black circle), H. crucifera var. brevidactyla (gray circle), H. guaraensis (empty circle), H. cardiostigmatica (gray triangle), H. spanophytica (black triangle), $H$. galeandriformis (black square) and $H$. montiswilhelminae (gray square). Only one collection was plotted for each locality. Based on Flora Neotropica base map no 1 .

also particularly suitable for agriculture. Fortunately, in the Federal District, five of the seven known species populations are found under protected areas. At least three populations of the species in Minas Gerais and the one in Bahia are in protected or remote areas. The collections from São Paulo were made in areas that are now densely human-populated and these populations probably disappeared.

Illustrations - Warming (1884: Tab. 8, fig. 6, based on the type of $H$. crucifera); Cogniaux (1893: t. 7, fig. 2, based on Barbosa Rodrigues original illustration of $H$. aphylla); Sprunger (1996: t. 64A, Barbosa Rodrigues original illustration of $H$. aphylla); Hoehne (1940: t. 98-II; based on Barbosa Rodrigues original illustration of $H$. aphylla); Pabst and Dungs (1975: fig. 112; based on Brade 16243 from São Paulo).

Additional specimens examined. BRAZIL. Bahia: Chapada Diamantina, Lençois, in the trail between Capão village and Lençois, 14 Sep 1996 (fl), Batista \& Oliveira 624 (CEN). Distrito Federal: Brazlândia, Chapada da Contagem, 17 Jan 1995 (fl), Batista 478 (CEN); Brazlândia, Chapada da Contagem, 25 Dec 1996 (fl), Batista 646 (CEN); Brazlândia, DF-240, near the intersection with DF-001, 25 Dec 1996 (fl), Batista 647 (CEN); Brasília, Brasília National Park, 27 Jan 1995 (fl), Batista \& Bianchetti 511 (CEN); Brasília, Lago Sul, 4 Jan 1995 (fl), Batista et al. 447 (CEN); Samambaia, DF-280, Furnas, 18 Dec 2001 (fl), Batista et al. 1271 (CEN); Taguatinga, área de proteção de manancial "Currais e Pedra", 2 Jan 2005 (fl), Batista et al. 1544 (BHCB); Taguatinga, south Taguatinga, 27 Nov 1989 (fl), Bianchetti \& Batista 825 (CEN); Brasília, Lago Sul, 4 Jan 1995 (fl), Oliveira 61 (UB); Brazlândia, DF-001, $15^{\circ} 44^{\prime} 9^{\prime \prime} \mathrm{S}, 48^{\circ} 5^{\prime} 12^{\prime \prime} \mathrm{W}, 21$ Nov 2004, Salles et al. 3559 (HEPH). Minas Gerais: Ouro Preto, Três Moinhos, 11 Mar 1975 (fl), Badini s.n. (OUPR 9704); 22 Mar 1975 (f1), Badini s.n. (OUPR 9703); Serra da Moeda, $20^{\circ} 16^{\prime}$ 26.3"S, 4357'29.0"W, 1451 m, 14 Jan 2007 (fl), Batista 1826 (BHCB); Ouro Branco, Serra do Ouro Branco, $20^{\circ} 30^{\prime} 10.6^{\prime \prime} \mathrm{S}, 43^{\circ} 39^{\prime} 24.5^{\prime \prime} \mathrm{W}, 1365$ m, 5 Mar 2008 (fl), Batista 2607 (BHCB); São Roque de Minas, Serra da Canastra National Park, 12 Mar 2000 (fl), Batista \& Lemos 1069 (CEN), Batista \& Lemos 1072 (CEN); Serra da Moeda, 5 Jan 2000 (fl), Batista \& Proite 979 (CEN); São Roque de Minas, Serra da Canastra National Park, $20^{\circ} 15^{\prime} 40.7^{\prime \prime} \mathrm{S}, 4^{\circ} 25^{\prime} 37.3^{\prime \prime} \mathrm{W}, 1370 \mathrm{~m}, 8$ Jan 2007 (fl), Batista et al. 1802 (BHCB), 20³'21.8"S, 46 27'35.4" W, 1455 m, 9 Jan 2007 (fl), Batista et al. 1809 (BHCB), $20^{\circ} 15^{\prime} 58.3^{\prime \prime} \mathrm{S}, 46^{\circ} 33^{\prime} 4.9^{\prime \prime} \mathrm{W}, 1409 \mathrm{~m}, 10$ Jan 2007 (fl), Batista et al. 1823 (BHCB); Delfinópolis, $1000 \mathrm{~m}, 22^{\circ} 12^{\prime}$ $30^{\prime \prime} \mathrm{S}, 47^{\circ} 06^{\prime} 16^{\prime \prime} \mathrm{W}, 14$ Jan 2003 (fl), Cavalcanti et al. 3074 (CEN); Serra da Moeda, 1400 m, 19 Dec 1989 (fl), Grandi \& Porto s.n. (BHCB 16762); Joaquim Felício, Serra do Cabral, 17 Jan 1996 (fl), Hatschbach et al. 64239 (MBM); São Gonçalo do Rio Preto, Rio Preto

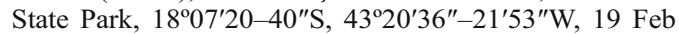
2002 (fl), Lombardi 4551 (BHCB); Lagoa Santa, Warming s.n. (AMES). São Paulo: São Paulo, between Vila Ema and São Bernardo, Mar 1940 (fl), Brade 16243 (HB, ICN, RB, SP, SPF); São Paulo, campo Congonhas, 2 Dec 1941 (fl), W. Hoehne s.n. (SPF 11072).

The narrow leaves that are appressed to the stem, which give the plant a leafless aspect (hence the name of the species described by Barbosa Rodrigues), along with the simple or discretely bipartite petals, and the tripartite lip with lateral segments curved upwards, are very characteristic and promptly identify $\mathrm{H}$. crucifera var. crucifera. However, among the material examined of the species some significant differences in the size of the flowers and details of column structure were observed. For instance, the length of the segments of the lip is variable, but the lateral segments are consistently about the same length or longer than the median segment, being (0.8-)1-1.3(-1.5) times as long as the median segment. Also, the space between the viscidia and the size of the auricles and rostellum showed some degree of variation. Throughout its distribution range the flower segments of $H$. crucifera var. crucifera are mainly green, but the specimens from Bahia 
TABLE I

NUMBER OF COLLECTIONS AND RECORDS OF HABENARIA CRUCIFERA AND RELATED SPECIES BY MONTH OF THE YEAR.

\begin{tabular}{|c|c|c|c|c|c|c|c|c|c|c|c|c|c|}
\hline \multirow[b]{2}{*}{ Taxa } & \multicolumn{7}{|c|}{ Rainy season ${ }^{a}$} & \multicolumn{5}{|c|}{ Dry season $^{\mathrm{a}}$} & \multirow[b]{2}{*}{ Total } \\
\hline & Oct & Nov & Dec & Jan & Feb & Mar & Apr & May & Jun & Jul & Aug & Sep & \\
\hline $\begin{array}{l}\text { Habenaria crucifera var. } \\
\text { crucifera (DF, MG, SP) }\end{array}$ & & 2 & 5 & 12 & 1 & 5 & & & & & & & 25 \\
\hline $\begin{array}{l}\text { Habenaria crucifera var. } \\
\text { crucifera (BA) }\end{array}$ & & & & & & & & & & & & 1 & 1 \\
\hline $\begin{array}{l}\text { Habenaria crucifera var. } \\
\text { brevidactyla }\end{array}$ & & 4 & 1 & 1 & & & & & & & & & 6 \\
\hline Habenaria cardiostigmatica & & & 1 & 5 & 5 & & & & & & & & 11 \\
\hline Habenaria galeandriformis & & & & 1 & 2 & 1 & & & & & & & 4 \\
\hline Habenaria guaraensis & & & 4 & 2 & & & & & & & & & 6 \\
\hline $\begin{array}{l}\text { Habenaria montiswilhelminae } \\
\text { (Guianas) }\end{array}$ & & & & & & 1 & & & 1 & 1 & 2 & & 5 \\
\hline $\begin{array}{l}\text { Habenaria montiswilhelminae } \\
\text { (DF, MG, GO) }\end{array}$ & & & 3 & 9 & 2 & & & & & & & & 14 \\
\hline $\begin{array}{l}\text { Habenaria montiswilhelminae } \\
\text { (South Brazil) }\end{array}$ & 1 & 1 & & 1 & & & & & & & & & 3 \\
\hline Habenaria spanophytica & & & 2 & 4 & 5 & 7 & 1 & & & & & & 19 \\
\hline
\end{tabular}

${ }^{a}$ The rainy and dry season periods presented here are referable to central and part of southeastern Brazil.

presented the petals and lip greenish-white. Some species such as H. glaucophylla Barb. Rodr. and $H$. nemorosa Barb. Rodr. have flowers with a similar morphology of the perianth, but are distinct by the broad, lanceolate, patent leaves.

The specimens in the collection Brade 16243, from the state of São Paulo, represent the southern range of the species, and differ from all other collections by the anterior petal segment that varies from a tooth-like projection to linear-filiform $(0.5-2.8 \mathrm{~mm}$ long, and up to $3 / 4$ the length of the posterior petal segment). The illustration of $H$. aphylla in Orchidaceae Brasilienses (Pabst \& Dungs, 1975: fig. 112) is based on this material and reproduces this characteristic. Additionally, the inflorescences are more crowded, the flowers are slightly smaller, the ovary + pedicel and the spur are shorter. Measurements from the specimens in this collection have not been included in the description presented here and will be published in the forthcoming Orchidaceae treatment for the Flora Fanerogâmica do Estado de São Paulo. It is possible that the availability of more material and a better characterization of these variants may show they deserve subspecific status.

On the other hand, other collections previously referred to $H$. aphylla are sufficiently different and are treated here as distinct taxa. The main differences are found in the habitat, size of the flowers, development of the lip lateral segments, morphology and length of the spur, and also on details of the column structure, particularly the morphology of the rostellum, the orientation of the lateral segments, and the development of the auricles.

Habenaria crucifera Rchb.f. \& Warm. var. brevidactyla J. A. N. Batista \& L. B. Bianchetti, var. nov. Type: Brazil. Distrito Federal: Taguatinga, Taguatinga Norte, área de proteção de manancial "Currais e Pedra", Floresta Nacional, 2 Jan 2005 (fl), J. A. N. Batista, K. Proite \& C. P. Lombardi 1545 (holotype: BHCB; isotypes: AMES, CEN, SP).

(Figs. 2, 4)

A varietate typica lobis lateraliblus labelli brevibus, 2-4(-5.5) $\mathrm{mm}$ longis et calcari brevi, $4.5-5 \mathrm{~mm}$ longo differt.

Terrestrial herbs. Stem erect, 49-66 cm long, including the inflorescence, $1.5-2 \mathrm{~mm}$ wide. Leaves 7-10, appressed to the stem, largest at the center of the stem, linear, narrow, 3.5-9 $\times 0.3-0.5 \mathrm{~cm}$. Inflorescence 7$8 \mathrm{~cm}$ long, few flowered, lax; bracts ovate, $7-$ $18 \times 5-7.5 \mathrm{~mm}$, acuminate, about the same size as the ovary + pedicel. Flowers 8-10, small, greenish, becoming greenish-yellow 
with age; ovary + pedicel 9-10 mm long, slightly arched. Sepals green, discretely mucronate, margin smooth; dorsal sepal concave, when flattened ovate, 4-5.5 $\times 3.5-$ $5 \mathrm{~mm}$; lateral sepals obliquely ovate-lanceolate, deflexed, 5-6.5 ×1.5-2 mm. Petals discretely bipartite, base whitish, turning light green towards the segments apices; posterior segment ovate-lanceolate, slightly falcate, 4$5.5 \mathrm{~mm} \times(1-) 1.5-1.8 \mathrm{~mm}$, acute, connivent with the dorsal sepal; anterior segment reduced to a tooth-like projection, inserted at the base of the posterior segment, $0.5-1 \mathrm{~mm}$ long. Lip distinctly tripartite, base whitish, turning light green towards the segments apices; undivided basal part short, $1-1.5 \times 1-$ $1.5 \mathrm{~mm}$; lateral segments erect or perpendicular to the median segment, linear-filiform, 2$4(-5.5) \mathrm{mm}$ long, the base perpendicular or forming a obtuse angle with the median segment; median segment, geniculate, 5-7 $(-8) \times 0.7-1 \mathrm{~mm}$. Spur pending, totally or partially covered by the bracts, clavate, shorter than the ovary + pedicel, $4.5-5 \mathrm{~mm}$ long, green, base $0.7 \mathrm{~mm}$ wide, apex 1.2$1.7 \mathrm{~mm}$ wide. Column erect, $2.8-3 \mathrm{~mm}$ high; connective emarginate, green; auricles fleshy, verrucose, whitish, $0.7 \times 1 \mathrm{~mm}$. Anther $1-$ $1.3 \mathrm{~mm}$ high, canals short, $0.8 \mathrm{~mm}$ long; hemipollinarium separated; viscidia $0.2 \times$ $0.2 \mathrm{~mm}, 1.3 \mathrm{~mm}$ apart from one another; caudicles $1 \mathrm{~mm}$ long, pollinia $1 \mathrm{~mm}$ long. Stigma lobes $1.8 \mathrm{~mm}$ long, green, receptive surface convex, turned forwards, closely parallel, free part $1 \mathrm{~mm}$ long, apex 0.7$0.8 \mathrm{~mm}$ wide, truncate, inner margin thickened, space between the stigma lobes circular. Rostellum $2 \mathrm{~mm}$ long, green, midlobe triangular, fleshy, obtuse, completely placed between the anther loci, $1-1.2 \mathrm{~mm}$ long, $0.6-0.7 \mathrm{~mm}$ high, side-lobes parallel throughout, $0.8-1 \times 0.4 \mathrm{~mm}$.

Etymology. - From the Latin brevi (short) and the Greek dactyl (finger), referring to the short lateral segments of the lip, when compared to H. crucifera var. crucifera.

Distribution.- The new variety is known so far only from two localities in the Federal District: the 'Reserva Ecologica do Guará' and the 'Área de proteção de manancial Currais e Pedra'. These two localities are ca. $11 \mathrm{~km}$ apart. In a published account of the Orchidaceae of the 'Reserva Ecologica do Guará' (Batista et al., 2005) and in a checklist of the Orchidaceae of the Federal District (Batista \& Bianchetti, 2003) H. crucifera var. brevidactyla was listed as $H$. aff. aphylla 1.

Habitat, ecology, and phenology.-The new variety occurs in seasonally humid grasslands (campo limpo estacionalmente úmido), over gray soil, associated with murundus at about $1000 \mathrm{~m}$. This is a common habitat for many Habenaria taxa, including $H$. crucifera var. crucifera, $H$. alpestris, $H$. ayangannensis Renz, H. guilleminii Rchb.f., $H$. heringeri, $H$. imbricata Lindl., H. juruenensis, H. subfiliformis Cogn., H. pungens Cogn., H. secundiflora and other terrestrial orchids such as Cleistes tenuis Rchb.f., Cyanaeorchis minor Schltr., Cyrtopodium fowliei L.C.Menezes, C. parviflorum Lindl., Galeandra paraguayensis Cogn., Liparis bifolia Cogn., Lyroglossa grisebachii and Platythelys paranaensis (Kraenzl.) Garay. Vegetative and reproductive growth is associated with the availability of water during the rainy season and flowering time occurs from the beginning to the peak of the rainy season, from November to early January (Table I). The bloom appears to be strictly related to brushfires which occur during the dry season. All known collections and observations of the variety were made in previously burned areas.

Conservation status. - In the two localities where the variety is known the population is composed of a few individuals restricted to a small area. About no more than ten specimens in flower were observed in each collection made by the authors. Using the World Conservation Union Red List Categories and Criteria (IUCN, 2001) the new taxon can be tentatively classified as Endangered EN (criteria B1 ab(iii) +2ab(iii); D).

Additional specimens examined. BRAZIL. Distrito Federal: Guará, Reserva Ecológica do Guará, 5 Nov 1989 (fl), Batista 11 (CEN), 24 Nov 1996 (fl), Batista 636 (CEN), Miranda 10 (UB).

Despite the high similarity with $H$. crucifera var. crucifera, the new variety can be easily distinguished by the shorter lateral segments of the lip (2-4(-5.5) $\mathrm{mm}$ long vs. (6-)7.5-10 (-12) $\mathrm{mm}$ long in H. crucifera var. crucifera) and the shorter spur (4.5-5 mm long vs. 6$10 \mathrm{~mm}$ long). Additionally, the flowers of the variety are usually slightly smaller (dorsal 

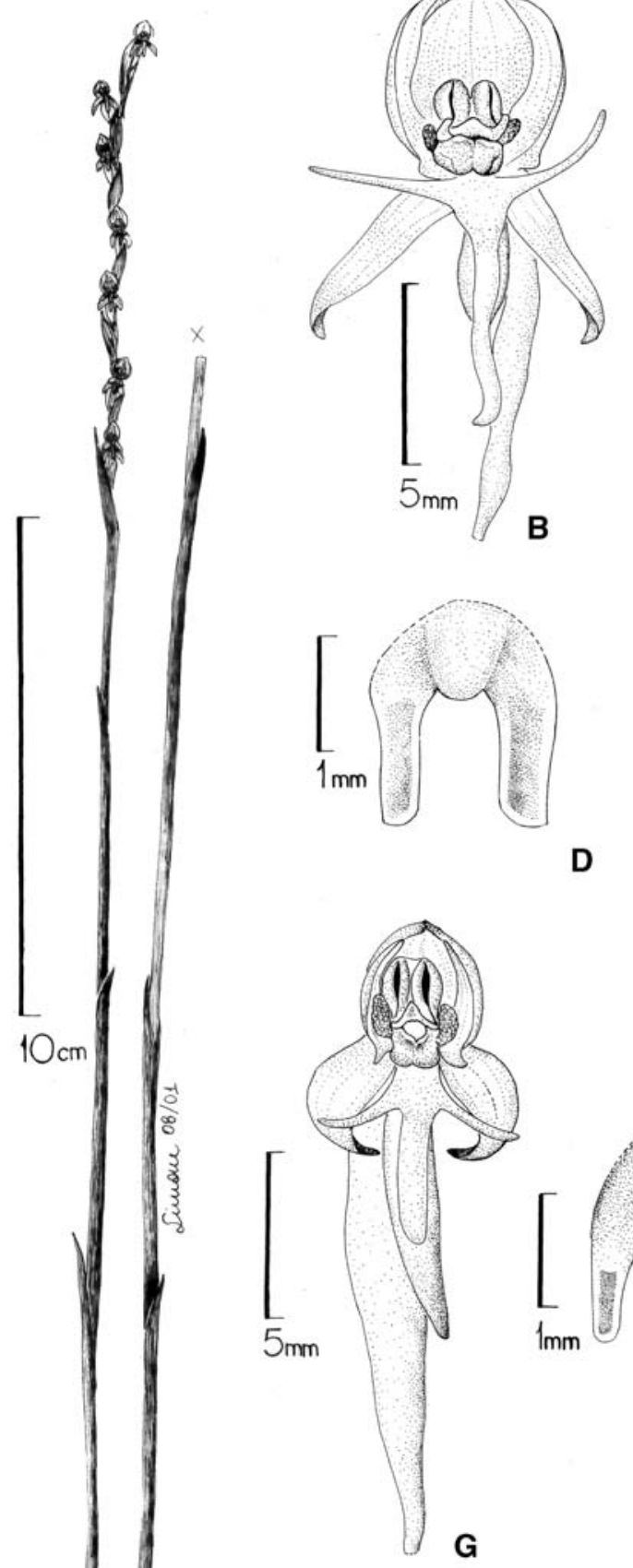
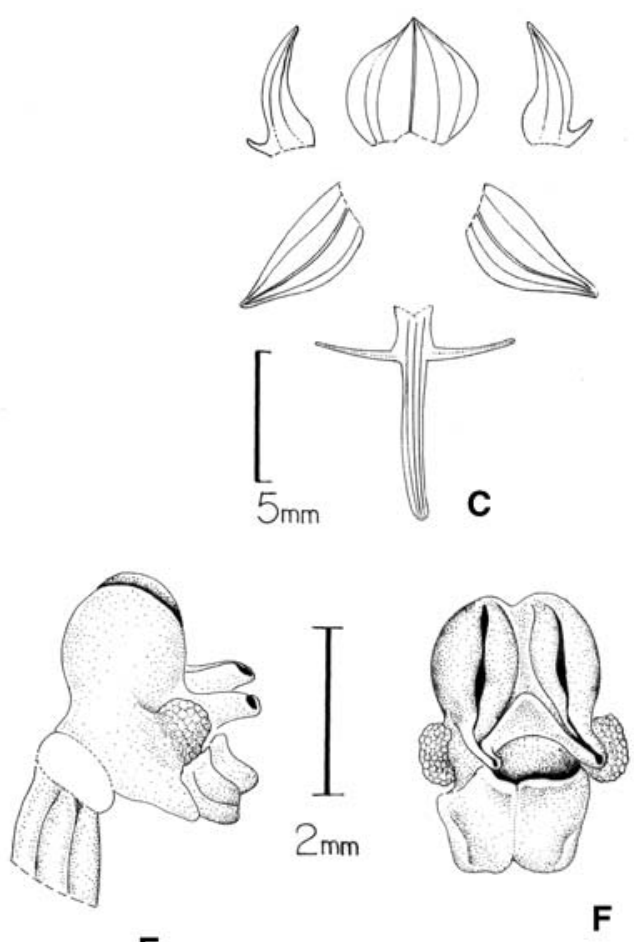

$\mathbf{F}$
D

A

E

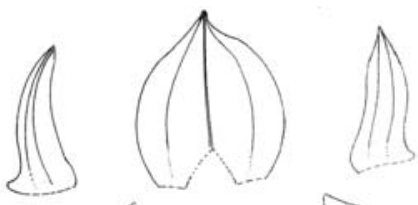

$10 \mathrm{~cm}$
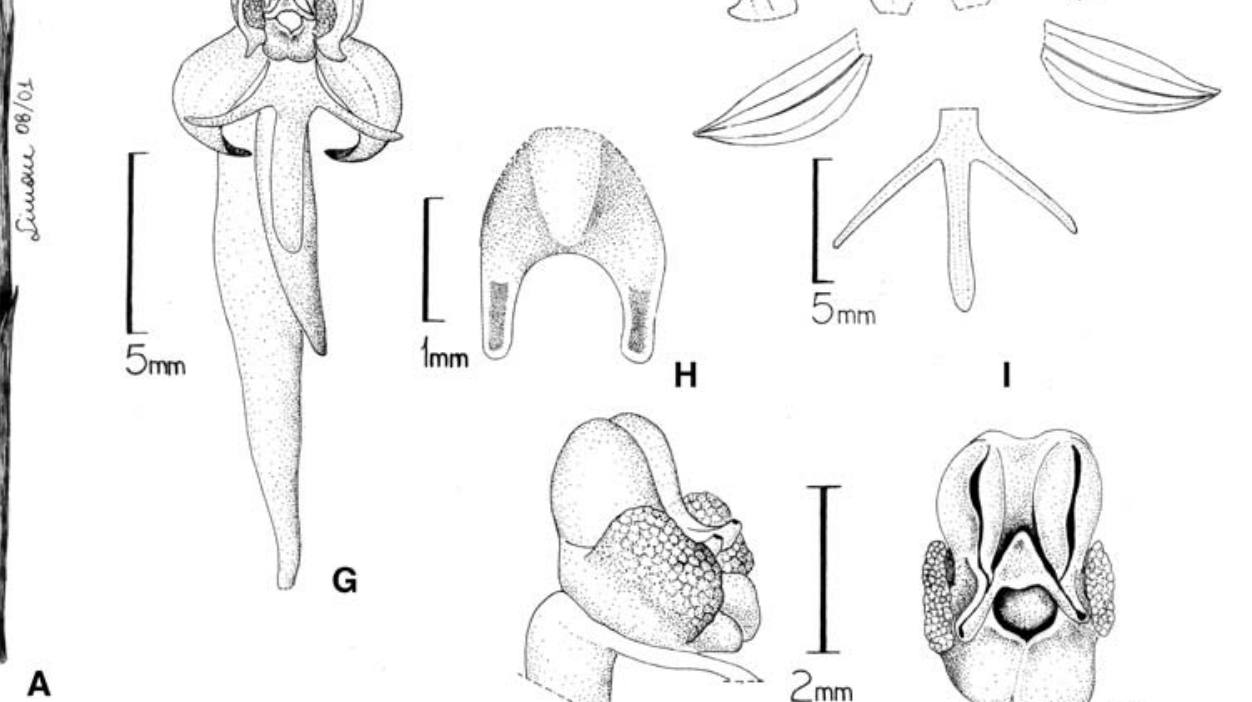

Fig. 4. Habenaria guaraensis and H. crucifera var. brevitactyla. A. Habenaria guaraensis, habit (Heringer 10803, UB). B-F. Habenaria crucifera var. brevidactyla (Batista 011, CEN). B. Flower, front view. C. Perianth. D. Rostellum, upper view. E. Column, lateral view. F. Column, front view. G-K. Habenaria guaraensis (Batista 136, CEN). G. Flower, front view. H. Rostellum, upper view. I. Perianth. J. Column, lateral view. K. Column, front view. 
sepal $4-5.5 \times 3.5-5 \mathrm{~mm}$ vs. $5-6(-7) \times 4-$ $5.5 \mathrm{~mm})$, the petals have a broader base and are somewhat triangular and less falcate, and the apex of the anterior segment of the petal is acute (vs. usually truncate in $H$. crucifera var. crucifera) (Fig. 1 and Table II). Since $H$. crucifera var. brevidactyla forms homogeneous populations and the distinctive characters are stable and not found in the range of variation of $H$. crucifera var. crucifera, we considered it quite distinct to be recognized as a variety. In defining the taxonomic rank of $H$. crucifera var. brevidactyla, we followed Stace (1989), who defined a variety as "a population of one or several biotypes, forming more or less distinct local facies of a species."

Habenaria cardiostigmatica J. A. N. Batista \& L. B. Bianchetti, sp. nov. Type: Brazil: Distrito Federal: Brasília, Setor de Mansões do Lago Norte, 6 Jan 1990 (fl), L. B. Bianchetti \& J. A. N. Batista 836 (holotype: CEN).

(Figs. 5, 6)

Habenariae cruciferae Rchb.f. \& Warm. var. cruciferae similis, sed habitatione flora campi gramineoherbaceo-suffruticosi (campo sujo dicti) vel campi aridi graminosi (campo limpo dicti), floribus minoribus (sepalo dorsali $3.5-4(-4.5) \times 3(-4) \mathrm{mm})$, stigmatibus uncinatis, aperatura inter stigmata calcar ducenti cordiformi differt.

Terrestrial herbs. Stem erect, 57-105 cm long, including the inflorescence, 2$3.5 \mathrm{~mm}$ wide. Leaves 10-14, appressed to the stem, largest at the center of the stem, linear, narrow, 6-20 $\times 0.3-0.8 \mathrm{~cm}$. Inflorescence (5-) $10-17(-24) \mathrm{cm}$ long, few to many flowered, loose to congest; bracts ovate, 5-12(-18) $\times 4$ $5.5 \mathrm{~mm}$, about the same size as the ovary + pedicel. Flowers (8-)13-25(-32), small, greenish white; ovary + pedicel mostly parallel to the rachis, 9-11 mm long, ovary slightly arched. Sepals light green, discretely mucronate, margin smooth; dorsal sepal concave, when flattened ovate, $3.5-4(-4.5) \times 3(-4) \mathrm{mm}$; lateral sepals obliquely ovate to ovate-lanceolate, deflexed, 4-5×2-2.5(-3) mm. Petals discretely bipartite, base whitish, turning light green towards the segments apices; posterior segment narrowly triangular, falcate, $3-4 \times 1 \mathrm{~mm}$, acute, free from the dorsal sepal; anterior segment reduced to a tooth-like projection, inserted at the base of the posterior segment, $0.5(-1) \mathrm{mm}$ long. Lip distinctly tripartite, base white, turn- ing creamy white or light green towards the segments apices; undivided basal part short, $0.7-1 \times 1-1.2 \mathrm{~mm}$; lateral segments linear-filiform, 6-8 $\mathrm{mm}$ long, the base perpendicular with the median segment; median segment, geniculate, 4.5-6×0.5-0.7 mm. Spur pending, totally or partially covered by the bracts, linear, slightly flexuose, shorter than the ovary+ pedicel, 7-9 $90.8-1 \mathrm{~mm}$, base whitish, apex green. Column erect, $2.5 \mathrm{~mm}$ high; connective emarginate, green; auricles fleshy, verrucose, whitish, $0.5 \times 0.5 \mathrm{~mm}$. Anther $1.3 \mathrm{~mm}$ high, canals short, $0.8 \mathrm{~mm}$ long; hemipollinarium separated; viscidia $0.1 \times 0.1 \mathrm{~mm}, 0.7 \mathrm{~mm}$ apart from one another; caudicles $0.8 \mathrm{~mm}$ long; pollinia $1 \mathrm{~mm}$ long. Stigma lobes $1.5 \mathrm{~mm}$ long, green, receptive surface convex, turned forwards, closely parallel, free part $1 \times$ $0.5 \mathrm{~mm}$ wide, apex truncate, uncinate, inner margin thickened, slightly verrucose, space between the stigma lobes heart shaped. Rostellum $1.8 \mathrm{~mm}$ long, green, midlobe triangular, fleshy, acute, completely placed between the anther loci, $1 \mathrm{~mm}$ long, $0.6 \mathrm{~mm}$ high, side-lobes parallel throughout, $0.8 \times$ $0.15-0.2 \mathrm{~mm}$.

Etymology.-From the Greek cardio (heart) and the Latin stigma (stigma), referring to the heart-shaped aperture between the stigma lobes that gives access to the spur.

Distribution. - The new species is known only from the Federal District and neighboring areas in the state of Goiás (Fig. 3). In Cristalina, Goiás, it was collected near the borderline with the state of Minas Gerais and it is expected that the species will be found in the cerrado area at the western part of that state. In a checklist of the Orchidaceae of the Federal District the species was listed as Habenaria aff. aphylla 3 (Batista \& Bianchetti, 2003).

Habitat, ecology, and phenology.-The new species occurs in dry grassy field (campo limpo) and grass-herb-subshrub field (campo sujo) vegetation, over deep, clay latosols or dry gray soil associated with rock outcrops, at about $1000 \mathrm{~m}$. Though superficially humid for some periods during the rainy season (October to March), these areas dry up completely during the dry season (April to September). In these same habitats several other terrestrial orchid species can be found, including Habenaria culicina Rchb.f. \& Warm., H. tamanduensis Schltr., H. trifida 
TABLE II

DiAgNOSTIC CHARACTERS BETWEEN $H$ CRUCIFERA VAR. CRUCIFERA AND THE RELATED SPECIES STUDIED IN THIS WORK.

\begin{tabular}{|c|c|c|c|c|c|c|c|}
\hline $\begin{array}{l}\text { Diagnostic } \\
\text { characters }\end{array}$ & $\begin{array}{l}\text { H. crucifera } \\
\text { var. crucifera }\end{array}$ & $\begin{array}{c}\text { H. crucifera } \\
\text { var. brevidactyla }\end{array}$ & $\begin{array}{c}H . \\
\text { cardiostigmatica }\end{array}$ & $\begin{array}{c}H . \\
\text { galeandriformis }\end{array}$ & $\begin{array}{c}H . \\
\text { guaraensis }\end{array}$ & $\begin{array}{c}H . \\
\text { montiswilhelminae }\end{array}$ & $\begin{array}{c}H . \\
\text { spanophytica }\end{array}$ \\
\hline $\begin{array}{l}\text { Stem height, } \\
\text { including the } \\
\text { inflorescence } \\
(\mathrm{cm})\end{array}$ & (19-)30-66 & $49-66$ & $57-105$ & $97-130$ & $78-97$ & $36-108$ & $(36-) 48-88$ \\
\hline $\begin{array}{l}\text { Dorsal sepal } \\
\text { length (mm) }\end{array}$ & $5-6(-7)$ & $4-5.5$ & $3.5-4(-4.5)$ & $4-4.5$ & $5-5.5$ & $(4-) 6-9(-12)$ & $(2.5-) 3$ \\
\hline $\begin{array}{l}\text { Petal posterior } \\
\text { segment } \\
\text { length }(\mathrm{mm})\end{array}$ & $4.5-6$ & $4-5.5$ & $3-4$ & $3.5-4.5$ & $4-5$ & $4.5-8(-10)$ & $2-3$ \\
\hline $\begin{array}{l}\text { Lip lateral } \\
\text { segments } \\
\text { length }(\mathrm{mm})\end{array}$ & $\begin{array}{l}(6-) 7.5-10 \\
(-12)\end{array}$ & $2-4(-5.5)$ & $6-8$ & $1.5-2$ & $3-4.5(-5)$ & $2-3.5(-5)$ & $3-3.5(-4.5)$ \\
\hline $\begin{array}{l}\text { Lip lateral } \\
\text { segment } \\
\text { length relative } \\
\text { to median } \\
\text { segment }\end{array}$ & $(0.8-) 1-1.5 \times$ & $0.5-0.7 \times$ & $1-1.6 \times$ & $0.2-0.4 \times$ & $0.8-1 \times$ & $0.2-0.4 \times$ & $1-1.3 \times$ \\
\hline $\begin{array}{l}\text { Lip median } \\
\text { segment } \\
\text { length }(\mathrm{mm})\end{array}$ & $5.5-8.5(-10)$ & $5-7(-8)$ & $4.5-6$ & $4-6$ & $4-5$ & $(5.5-) 8-10(-13)$ & $3(-4.5)$ \\
\hline $\begin{array}{l}\text { Spur length } \\
\quad(\mathrm{mm})\end{array}$ & $6-10$ & $4.5-5$ & $7-9$ & $(5-) 6.8-8.3$ & $8-10.5$ & $7-12$ & $7-9$ \\
\hline Spur shape & clavate & clavate & linear & clavate & linear & clavate & clavate \\
\hline $\begin{array}{l}\text { Anther canal } \\
\text { length (mm) }\end{array}$ & $1-1.3$ & 0.8 & 0.8 & 0.8 & 0.8 & $1.3-2$ & $0.4-0.5$ \\
\hline $\begin{array}{l}\text { Distance } \\
\text { between } \\
\text { viscidia }(\mathrm{mm})\end{array}$ & $1.2-1.5$ & 1.3 & 0.7 & 1 & $1.3-1.5$ & $1.8-2.8$ & 0.2 \\
\hline $\begin{array}{l}\text { Space between } \\
\text { stigma lobes }\end{array}$ & circular & circular & heart shaped & circular & circular & circular & circular \\
\hline $\begin{array}{l}\text { Rostellum } \\
\text { side-lobes } \\
\text { orientation }\end{array}$ & parallel & parallel & parallel & parallel & parallel & parallel & convergent \\
\hline
\end{tabular}

Kunth, Cyrtopodium poecilum Rchb.f. \& Warm., C. brandonianum Barb. Rodr., Cleistes paranaensis (Barb. Rodr.) Schltr. Galeandra junceoides Barb. Rodr., Pelexia cuculligera (Rchb.f. \& Warm.) Schltr. and Veyretia sagittata (Rchb.f. \& Warm.) Szlach. The species grows and flowers at the peak of the rainy season, from late December to February (Table I). As with most orchids and other Habenaria species from grasslands, blooming is associated with brushfires that occur during the dry season. All collections or field observations of the species by the authors were done in previously burned areas.

Conservation status.-Habenaria cardiostigmatica is an uncommon species. In each of the three collections of the species made by the authors no more than three to six blooming individuals were observed. The only site where the authors knew and collected the species, in the 'Setor de Mansões do Lago Norte', Brasília, Federal District, was occupied by irregular joint estates and this population of the species was lost. Of the other known collections, none came from a conservation unit. Considering the geographic distribution and using the World Conservation Union Red List Categories and Criteria (IUCN, 2001) the species can be tentatively classified as Vulnerable VU (criteria B2ab(iii); D2).

Additional specimens examined. BRAZIL. Distrito Federal: Brasília, Setor de Mansões do Lago Norte, 11 Jan 1990 (fl), Batista \& Bianchetti s.n. (CEN), 6 Feb 1990 (fl), Bianchetti 832 (CEN); Bacia do Rio São Bartolomeu, 2 Feb 1981 (fl), Heringer et al. 6121 (AMES, IBGE, MG); $25 \mathrm{~km}$ E of Brasília, 28 Jan 1966 (fl), Irwin 12086 (HB, NY); E. of Lago Paranoá, 25 Feb 1970 (fl), Irwin et al. 26600 (UB). Goiás: Cocalzinho, Vale do Rio Areias, 18 Jan 1993 (fl), Chagas s.n. (HEPH 7768-2); Cristalina, km 3.3 in highway BR-251 from the Goiás-Minas Gerais state-line, $16^{\circ} 02^{\prime} \mathrm{S}, 47^{\circ} 22^{\prime} \mathrm{W}, 950 \mathrm{~m}$, 8 Feb 1988 (fl), Valls 11577 (CEN).

As far as we could determine, this species was first collected in 1966 by H. S. Irwin et al. in Brasília and identified as $H$. aphylla by Pabst. In the general morphology and position 

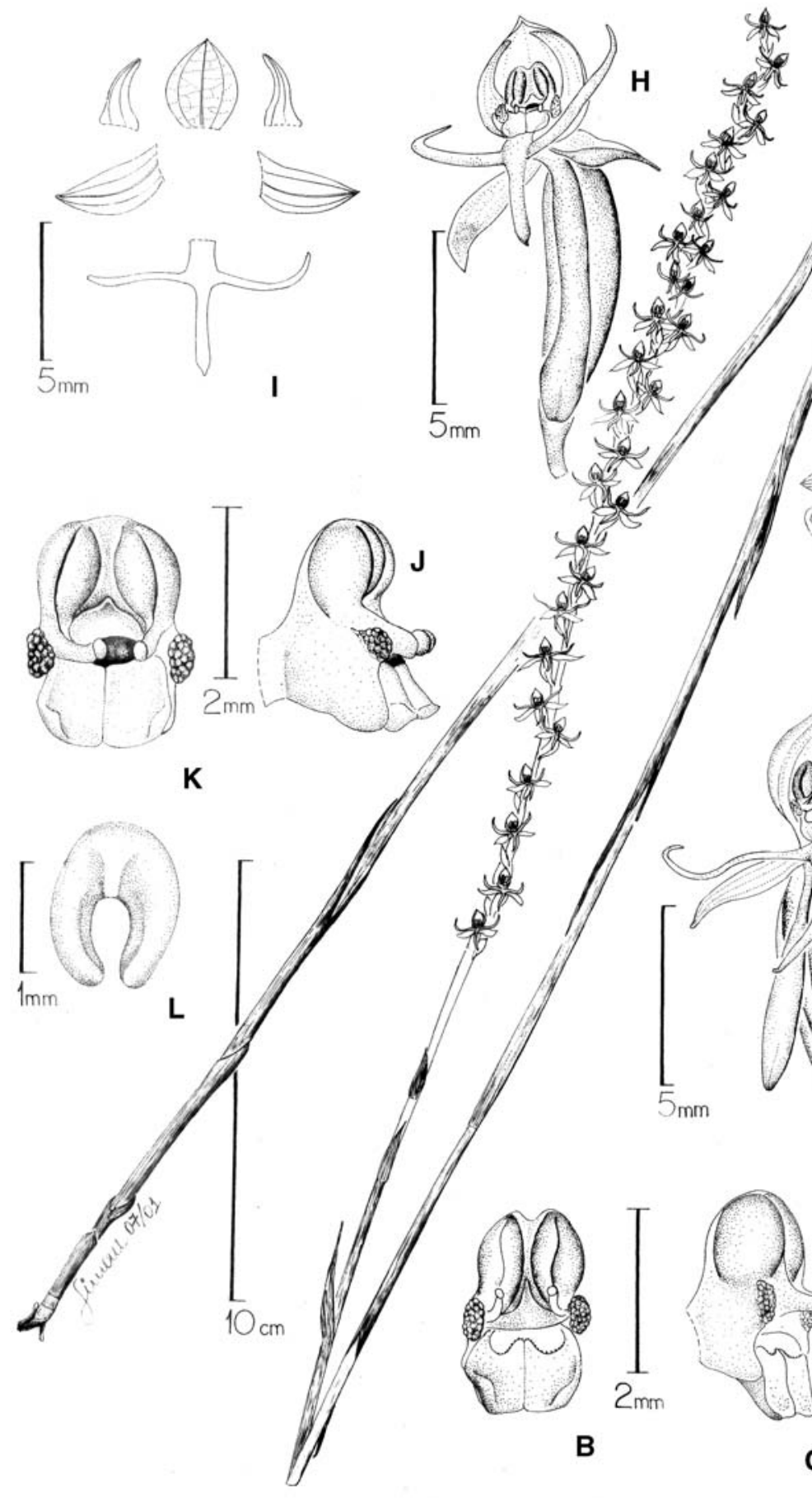

A

Fig. 5. Habenaria cardiostigmatica and H. spanophytica. A-G. Habenaria cardiostigmatica. A. Habit (Irwin et al. 26600, UB). B. Column, front view. C. Column, lateral view. D. Stigma lobes, upper view. E. Flower, front view. F. Rostellum, upper view. G. Perianth (B-G, Bianchetti \& Batista 836, CEN). H-L. Habenaria spanophytica (Batista et al. 730, CEN). H. Flower, $3 / 4$ view. I. Perianth. J. Column, lateral view. K. Column, front view. L. Rostellum, upper view. 

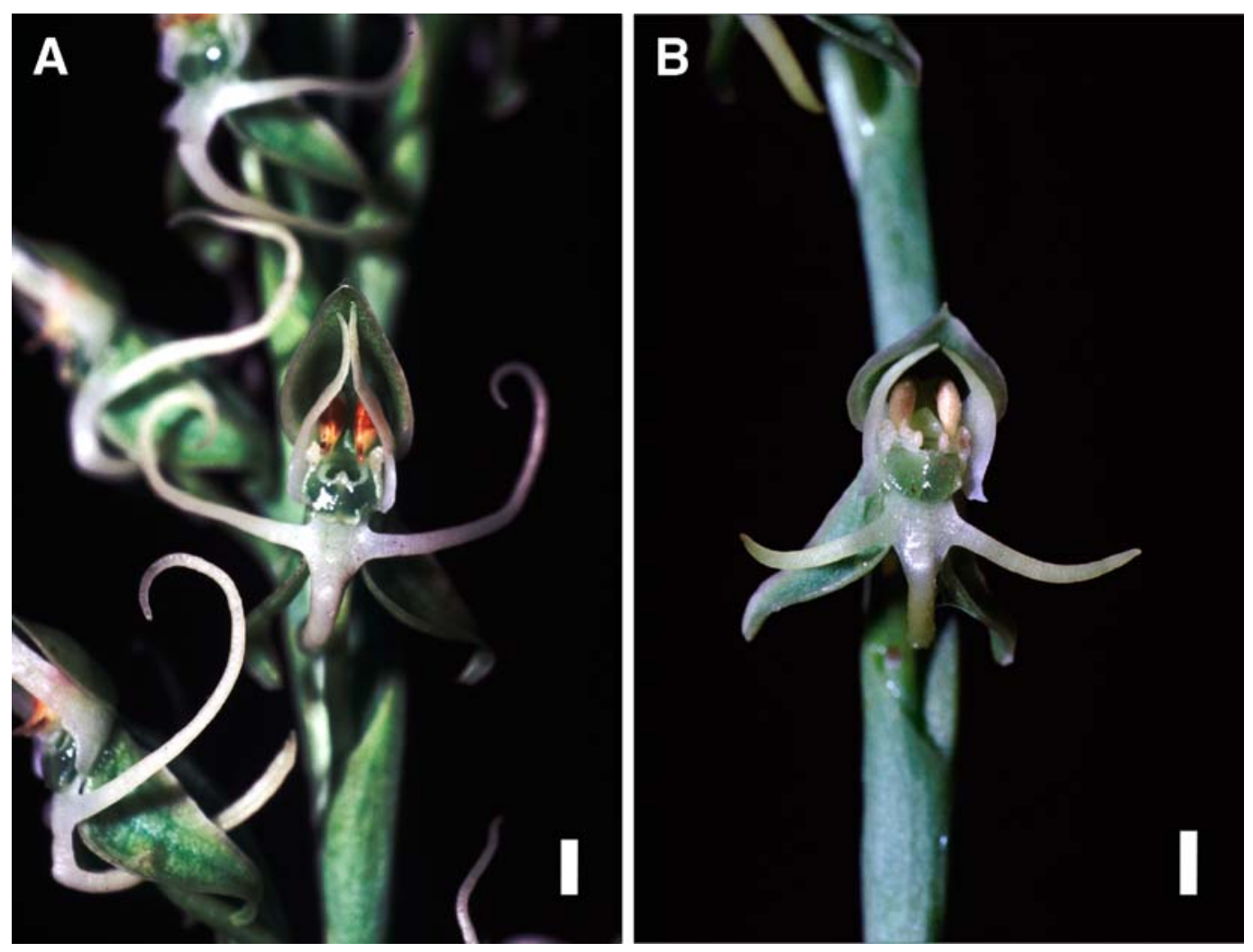

Fig. 6. Flowers from live specimens. Habenaria cardiostigmatica. A. From 'Setor de Mansões do Lago Norte', Brasília, Federal District. Habenaria spanophytica. B. From Sucupira farm, Núcleo Bandeirante, Federal District. Scale bars $=1 \mathrm{~mm}$.

of the flower segments, the new species is similar to $H$. crucifera var. crucifera, but $H$. cardiostigmatica has smaller flowers (dorsal sepal $3.5-4(-4.5) \times 3(-4) \mathrm{mm}$ vs. $5-6(-7) \times 4-$ $5.5 \mathrm{~mm}$ in H. crucifera var. crucifera), a linear spur (vs. clavate), and a distinct column structure with the space between the stigma lobes heart-shaped (vs. circular) and the stigma lobes uncinate (vs. straight, not uncinate). These and additional differences are shown in Table II. In column morphology $H$. cardiostigmatica is similar to $H$. mystacina Lindl., also from section Nudae. In both species the rostellum midlobe is slender, with an acute apex, the rostellum arms are slender, narrow, the two functional stigma lobes are uncinate and the space between them, which gives access to the spur, is heart-shaped. However, $H$. mystacina has deeply bipartite petals, the lateral segments of the petals and lip are densely pubescent and the species seems to be related to other taxa with hairy segments such as $H$. pubidactyla J.A.N. Batista \& Bianchetti (Batista \& Bianchetti, 2006).

Habenaria galeandriformis Hoehne, Bot. Jahrb. Syst. 68: 128. 1937. Type: Brazil. São Paulo: Morro Pellado, campo, Jan 1901, G. Edwall in CGGSP 6000 (holotype: SP).

(Fig. 7)

Terrestrial herbs. Stem erect, 97-130 cm long, including the inflorescence, $3 \mathrm{~mm}$ wide. Leaves 12-13, appressed to the stem, largest at the center of the stem, linear, narrow, (3-)9.5$19 \times(0.4-) 0.6-0.8 \mathrm{~cm}$. Inflorescence $15-18 \mathrm{~cm}$ long, few to many flowered, loose; bracts ovate to lanceolate, $(7-) 14-20(-30) \times 4-6 \mathrm{~mm}$, longer than the ovary+ pedicel. Flowers 14-20, small, green; ovary + pedicel mostly parallel to the rachis, 9-12 $\mathrm{mm}$ long, ovary straight. Sepals mucronate, margin smooth; dorsal sepal ovate, 4-4.5×3.5-4 $\mathrm{mm}$; lateral sepals obliquelyovate to obliquely-elliptical, $4.8-6 \times 2-$ 
$2.3 \mathrm{~mm}$. Petals discretely bipartite; posterior segment falcate, $3.5-4.5 \times 1-1.5 \mathrm{~mm}$, connivent with the dorsal sepal; anterior segment reduced to a tooth-like projection, inserted at the base of the posterior segment, $1-1.3 \mathrm{~mm}$ long. Lip discretely tripartite; undivided basal part short, $0.5-1 \times 1 \mathrm{~mm}$; lateral segments perpendicular to the median segment, linear-filiform, $1.5-2 \mathrm{~mm}$ long; median segment linear, 4-6×0.8-1 mm. Spur pending, shorter than the ovary + pedicel, slightly clavate, $(5-) 6.8-8.3 \times 1.2-$ $1.8 \mathrm{~mm}$. Column erect, $2.5-3 \mathrm{~mm}$ high; connective emarginate; auricles fleshy, verrucose, $0.5-0.7 \times 0.7-1.3 \mathrm{~mm}$. Anther $1.5 \mathrm{~mm}$ high, canals $0.8 \mathrm{~mm}$ long; hemipollinarium separated; viscidia $0.3 \times$ $0.3 \mathrm{~mm}$, about $1 \mathrm{~mm}$ apart from one another; caudicles $1.3 \mathrm{~mm}$ long; pollinia $1 \times 0.8 \mathrm{~mm}$. Stigma lobes $2 \mathrm{~mm}$ long, receptive surface convex, turned forwards, closely parallel, free part $1.2 \mathrm{~mm}$ long, apex $1 \mathrm{~mm}$ wide, space between the stigma lobes circular. Rostellum $2 \mathrm{~mm}$ long, midlobe triangular, fleshy, obtuse, completely placed between the anther loci, $1 \mathrm{~mm}$ long, $0.7 \mathrm{~mm}$ high, side-lobes parallel throughout, $1 \times 0.4 \mathrm{~mm}$.

Distribution.-Known only from the states of São Paulo (Morro Pellado, now Itirapina, the type locality) and Mato Grosso (Municipalities of Cuiabá and Itiquira).

Habitat and phenology.-This species seems to be typical of low altitude, dry grassy fields (campo limpo), at elevations of 150 to $700 \mathrm{~m}$, but one of the collections of the species is recorded for wet places. Flowering time occurs during the rainy season, from January to March (Table I).

Conservation status. - Based on the collection data available and using the World Conservation Union Red List Categories and Criteria (IUCN, 2001) the species can be tentatively classified as Endangered EN (criteria B2ab(iii); D).

Illustrations.-Hoehne (1937: t. 12; 1940: tab. 98, fig. 1. illustration of the type); Pabst and Dungs (1975: fig. 119, based on the holotype).

Additional specimens examined. BRAZIL. Mato Grosso: Itiquira, 12 Feb 1974, Hatschbach 34046 (MBM); Cuiabá, São José da Serra, 12 Feb 1974, Hatschbach 34075 (MBM); Cuiabá, BR-364, near
Pindaival stream, 11 Mar 1975, Hatschbach et al. 36074 (MBM).

Habenaria galeandriformis was described from a single specimen with immature flowers and its identity was unclear for a long time. In the original description and illustration the flowers are recorded as small and the petals are simple. Beyond the type, we have seen only three additional collections made by Gert Hatschbach in the state of Mato Grosso. The specimens from Mato Grosso differ from the original description and illustration because they have slightly larger flowers and a short tooth-like segment at the base of the posterior petal. Despite these differences, the combination of tall plants, from dry places, imbricate bracts, small flowers, short lateral segments of the lip, and a clavate spur agrees well with $H$. galeandriformis and we tentatively assign the three examined specimens from Mato Grosso to this species. The only morphological difference separating $H$. galeandriformis from $H$. montiswilhelminae is the size of the flower parts (Table II). Although the number of collections of $H$. galeandriformis is low, the combination of tall plants with small flowers from low altitude cerrado seems to be constant, and for the moment we prefer to keep them as a separate species. Nevertheless, considering the similarity between these two species, it is possible that the collection of more material and a better characterization of $H$. galeandriformis and $H$. montiswilhelminae may show they are indeed conspecific.

Habenaria guaraensis J. A. N. Batista \& L. B. Bianchetti, sp. nov. Type: Brazil: Distrito Federal: Guará, Reserva Ecológica do Guará, 18 Dec 2000 (fl), J. A. N. Batista 1096 (holotype: CEN; isotype: BHCB). (Figs. 2, 4)

Habenariae cruciferae Rchb.f. \& Warm. var. cruciferae similis, sed habitatione campi graminosi perpetuo humidi (campo limpo inundavel dicti) supra solum instabilem, hydromorphicum, lobis lateralibus labelli brevioribus (3-4.5(-5) mm longis), deflexis, canalibus antherarum brevioribus ( $0.8 \mathrm{~mm}$ longis), et auriculis majoribus $(1.3 \times 1.5-1.8 \mathrm{~mm})$ differt.

Terrestrial herbs. Stem erect, 78-97 cm long, including the inflorescence, $2-3.5 \mathrm{~mm}$ 
wide. Leaves 9-12, appressed to the stem, largest at the center of the stem, linear, narrow, $6.5-12 \times 0.4-0.8 \mathrm{~cm}$. Inflorescence $10-13 \mathrm{~cm}$ long, few flowered, loose; bracts oblong-lanceolate, $10-23 \times 4-6 \mathrm{~mm}$, caudate, longer than the ovary + pedicel. Flowers 7 12, small, green; ovary + pedicel mostly parallel to the rachis, $12-16 \mathrm{~mm}$ long, ovary straight. Sepals mucronate, green, main veins slightly marked in darker green, margins smooth, whitish; dorsal sepal concave, when flattened ovate-lanceolate, $5-5.5 \times 4-4.5 \mathrm{~mm}$; lateral sepals obliquely oblong-lanceolate, reflexed, 5-6 $\times 2-2.5 \mathrm{~mm}$. Petals discretely bipartite, base whitish, turning light green towards the segments apices; posterior segment lanceolate, falcate, $4-5 \times 1.3-1.5 \mathrm{~mm}$, acute, connivent with the dorsal sepal, anterior segment reduced to a tooth-like projection, inserted at the base of the posterior segment, (0.5-)1 $\mathrm{mm}$ long. Lip distinctly tripartite, base whitish, turning light green towards the segments apices; undivided basal part short, $1-1.5 \times 1.2-1.5 \mathrm{~mm}$; lateral segments deflexed, subreflexed, linear-filiform, 3-4.5(-5) $\mathrm{mm}$ long, the base forming an acute angle with the median segment; median segment linear, geniculate, 4-5 $\times$ $1 \mathrm{~mm}$. Spur pending, totally or partially covered by the bracts, linear, shorter than the ovary + pedicel, $8-10.5 \times 1.2-1.5 \mathrm{~mm}$, green, apex acute. Column erect, 3-3.5 mm high; connective emarginate, green; auricles fleshy, verrucose, whitish, $1.3 \times 1.5-1.8 \mathrm{~mm}$, laterally covering the anther canals and rostellum side-lobes. Anther $1.5 \mathrm{~mm}$ high, canals short, $0.8 \mathrm{~mm}$ long; hemipollinarium separated; viscidia $0.2-0.3 \times 0.2-0.3 \mathrm{~mm}$, $1.3-1.5 \mathrm{~mm}$ apart from one another; caudicles $1.2 \mathrm{~mm}$ long. Stigma lobes $2.3 \mathrm{~mm}$ long, green, receptive surface convex, turned forwards, closely parallel, free part $0.8-1 \times 0.8$ $1 \mathrm{~mm}$, apex truncate, inner margin thickened, space between the stigma lobes circular. Rostellum 2-2.3 mm long, green, midlobe triangular, fleshy, subacute, completely placed between the anther loci, $1 \mathrm{~mm}$ long, $1.3 \mathrm{~mm}$ high, side-lobes parallel throughout, $1.3 \times 0.5 \mathrm{~mm}$.

Etymology.-The new species is named after the Guará Ecological Reserve.

Distribution. The new species is so far known only from the 'Reserva Ecologica do
Guará' a small preservation unit with $1.94 \mathrm{~km}^{2}$ located in the Federal District. Despite the small area, 103 taxa of Orchidaceae occur in the reserve, including 32 Habenaria. In a published account of the Orchidaceae of the reserve (Batista et al., 2005) and in a checklist of the Orchidaceae of the Federal District (Batista \& Bianchetti, 2003), H. guaraensis was listed as H. aff. aphylla 2.

Habitat, ecology, and phenology.-The new species occurs in permanently humid grassland (campo limpo inundável), in dark, water saturated, hydromorphic soil, with water over the surface, usually growing near the border of flooded gallery forests at about $1000 \mathrm{~m}$. This habitat is typical of other terrestrial orchid species which demand watersaturated soil, such as Phragmipedium vittatum (Vell.) Rolfe, Bletia catenulata Ruiz \& Pavon, Cyrtopodium paludicolum Hoehne, Oncidium hydrophilum Barb. Rodr., Sarcoglottis uliginosa Barb. Rodr. and several Habenaria such as H. leucosantha Barb. Rodr., H. nuda Lindl. var. pygmaea Hoehne, H. gourlieana Gill. ex Lindl., H. edwallii Cogn., H. balansae Cogn., and $H$. pubidactyla ssp. brasiliensis J. A. N. Bat. \& Bianch. Vegetative and reproductive growth is associated with rainfall, and blooming time occurs at the peak of the rainy season, during December and January (Table I). The bloom appears to be strictly related to brushfires during the dry season. All collections of the variety by the authors were made in previously burned areas.

Conservation status. - In each of the three collections of the species made by the authors no more than about five blooming individuals were observed. Using the World Conservation Union Red List Categories and Criteria (IUCN, 2001) H. guaraensis can be tentatively classified as Critically Endangered CR (criteria B1ab (iii) $+2 \mathrm{ab}($ iii); D).

\footnotetext{
Additional specimens examined. BRAZIL. Distrito Federal: Reserva Ecológica do Guará, 6 Jan 1990 (fl), Batista 56 (CEN, SP); 23 Dec 1990 (fl), Batista 136 (CEN); Zoobotânico, 20 Dec 1965 (fl), Heringer 10803 (UB, HB).
}

This taxon was first collected by E. P. Heringer in 1965 and identified as H. aphylla by Pabst. The new species is similar to $H$. crucifera var. crucifera but differs by growing in water-saturated, unstable, hydromorphic soil 


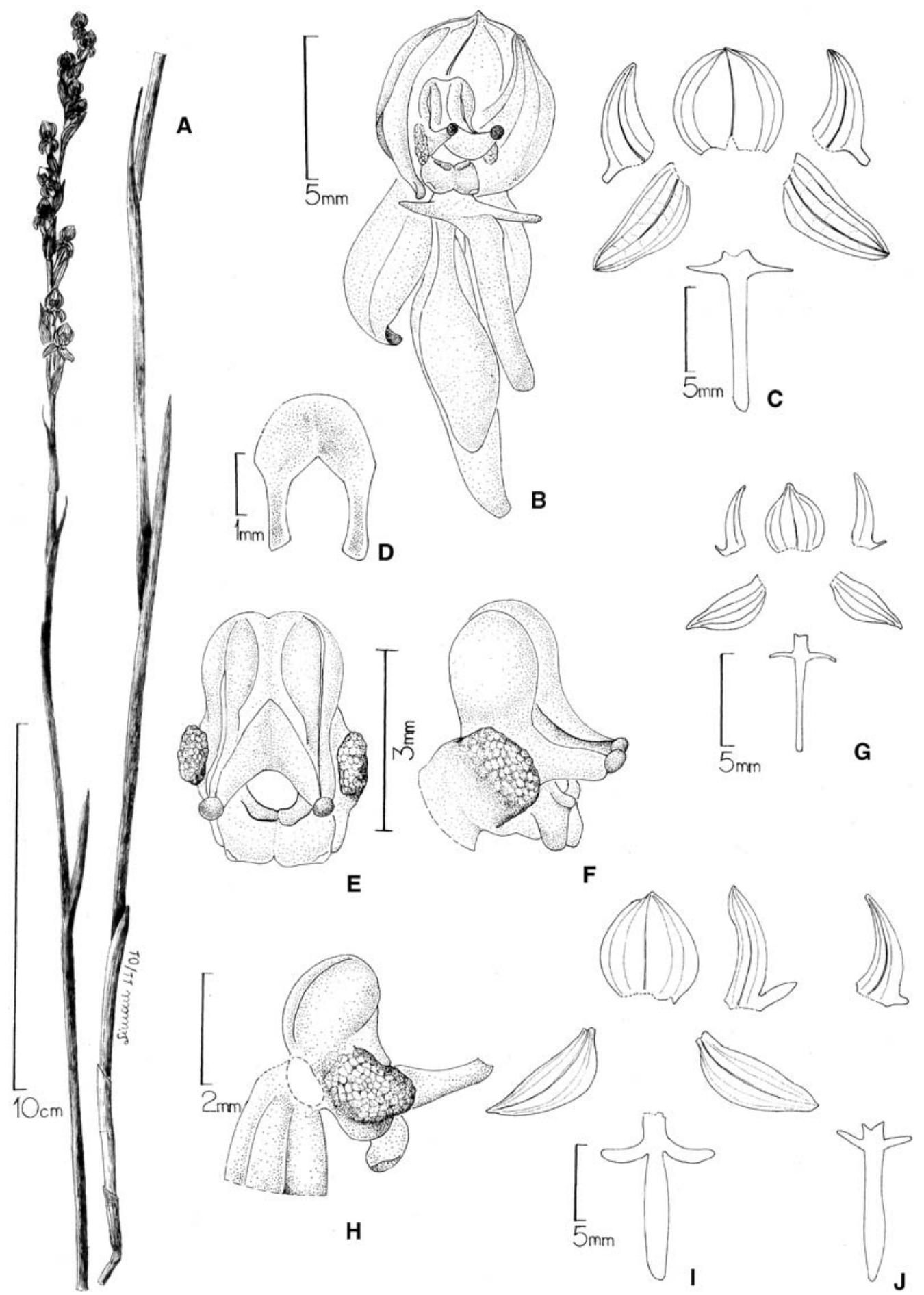

Fig. 7. Habenaria montiswilhelminae and H. galeandriformis. A-F. Habenaria montiswilhelminae (Batista 644, CEN). A. Habit. B. Flower, $3 / 4$ view. C. Perianth. D. Rostellum, upper view. E. Column, front view. F. Column, lateral view. G. Habenaria galeandriformis, perianth (Hatschbach 34075, MBM). H-J. Habenaria montiswilhelminae (Bertioli 012, CEN). H. Column, lateral view. I. Perianth. J. Perianth, variant. 
(vs. stable, seasonally humid or dry soil). Morphologically, the new species is characterized by the proportionally longer ovary+ pedicel (12-16 mm long vs. 9-14 $\mathrm{mm}$ long in $H$. crucifera var. crucifera), the evidently mucronate sepals (vs. obscurely mucronate), the shorter (3-4.5(-5) mm long) and deflexed lateral segments of the lip (vs. longer, (6-)7.5$10(-12) \mathrm{mm}$ long, and erect or perpendicular to the median segment), the shorter median segment of the lip (4-5 mm long vs. 5.5-8.5(-10) $\mathrm{mm}$ long), the shorter anther-canals $(0.8 \mathrm{~mm}$ long vs. $1-1.3 \mathrm{~mm}$ long), and the larger auricles $(1.3 \times 1.5-1.8 \mathrm{~mm})$, which cover most of the anther-canals and part of the stigma lobes (vs. smaller, $0.6-1 \times 0.7-0.8 \mathrm{~mm}$, and not covering much of the anther-canals and stigma lobes in H. crucifera var. crucifera).

Habenaria montiswilhelminae Renz, Candollea 47(2): 500. 1992. Type: Suriname. Wilhelmina Gebergte, on the ascent to the granitic top $1040 \mathrm{~m}$ from Oost-River, $3^{\circ} 35^{\prime}$ $\mathrm{N}, 56^{\circ} 20^{\prime} \mathrm{W}, 1$ Aug 1926, G. Stahel 580 (holotype: U-n.v.).

(Figs. 7, 8)

Terrestrial herbs. Stem erect, $36-108 \mathrm{~cm}$ long, including the inflorescence, $1.5-4.5 \mathrm{~mm}$ wide. Leaves 5-15, appressed to the stem or almost spread, largest at the lower half or at the center of the stem, linear, narrow, 4-20 $\times 0.3$ $0.8 \mathrm{~cm}$. Inflorescence $7-18 \mathrm{~cm}$ long, few to many flowered, loose; bracts ovate, caudate, 10 $30 \times 4-8 \mathrm{~mm}$, longer than the ovary + pedicel. Flowers 3-19, medium sized, green; ovary + pedicel mostly parallel to the rachis, $(10-) 13$ $20 \mathrm{~mm}$ long, ovary straight to slightly arched. Sepals discretely to clearly mucronate, margin smooth; dorsal sepal concave, when flattened roundish, (4-)6-9(-12) ×(4-)5.5-7(-9) $\mathrm{mm}$; lateral sepals obliquely ovate-lanceolate, (5.5-) $8-10(-13) \times(2-) 2.5-3(-4) \mathrm{mm}$, deflexed. Petals discretely bipartite; posterior segment narrowly-oblong, oblong or lanceolate to lanceolate-ovate, falcate, $4.5-8(-10) \times(1.2-)$ 2-2.5 mm, obtuse to acute, connivent with the dorsal sepal; anterior segment reduced to a tooth-like projection, inserted at the base of the posterior segment, linear, 1-3 mm long. Lip discretely tripartite; undivided basal part short, $0.7-2 \times 1.2-1.5 \mathrm{~mm}$; lateral segments erect, perpendicular to the median segment or slightly deflexed, linear-filiform, 2-3.5(-5) mm long; median segment linear, geniculate, (5.5-)8-10($13) \times 0.8-1.5 \mathrm{~mm}$. Spur pending, totally or partially covered by the bracts, clavate, shorter than the ovary + pedicel, 7-12 $\mathrm{mm}$ long, green, base $0.5-1 \mathrm{~mm}$ wide, apex (1.5-)2-3(-4) $\mathrm{mm}$ wide. Column erect, 4-4.5 mm high; connective narrow, emarginate, green; auricles fleshy, verrucose, whitish, 0.8-1.5 $\times 1-1.7 \mathrm{~mm}$. Anther $1.8-2 \mathrm{~mm}$ high, canals $1.3-2 \mathrm{~mm}$ long; hemipollinarium separated; viscidia $0.4-0.6 \mathrm{~mm}$ long, $1.8-2.8 \mathrm{~mm}$ apart from one another; caudicles $2-2.5 \mathrm{~mm}$ long; pollinia $1.3-1.5 \times$ $0.8-1 \mathrm{~mm}$. Stigma lobes oblong, 2-2.5 mm long, green, receptive surface convex, turned forwards, closely parallel, free part 1.3-2×0.8-1 $(-1.5) \mathrm{mm}$ long, apex truncate, $1 \mathrm{~mm}$ wide, inner margin thickened, space between the stigma lobes circular. Rostellum 2.7-3 mm long, greenish; midlobe triangular, fleshy, acute, completely placed between the anther loci, 1.2$1.5 \mathrm{~mm}$ long, $1.5-1.8 \mathrm{~mm}$ high, side-lobes parallel throughout, $2 \mathrm{~mm}$ apart from one another, $1.3-1.8 \times 0.4-0.5 \mathrm{~mm}$.

Distribution.-From the Guianas (Suriname and French Guiana) to the state of Rio Grande do Sul in southern Brazil, including the states of Goiás, Minas Gerais, Paraná and the Federal District. Most likely it should be expected to be found in the states of Pará and Tocantins, in northern Brazil.

Habitat, ecology, and phenology.-The habitat and phenology of the species are highly variable and related to geographical distribution. While plants from the Guianas grow on wet places in granitic outcrops, plants from the Federal District and Goiás were collected on dry grassy fields (campo limpo), grass-herbsubshrub field (campo sujo) and semideciduos xeromorphic medium tall forest (cerrado sensu stricto), over deep, clay latosols. Plants from the states of Minas Gerais (Serra da Canastra), Paraná, and Rio Grande do Sul were found in seasonally or permanently humid grassy fields, over dark, hydromorphic soil. In central Brazil plants from Goiás, Minas Gerais and the Federal District flowered at the peak of the rainy season, from December to February. Plants from the state of Paraná, in Southern Brazil, were collected in flower earlier, at the beginning of the rainy season, in October and November. Plants from the Guianas were collected in flower from March to August (Table I). In central, southeastern and southern 
Brazil, all collections of the species by the authors were made in previously burned areas. Conservation status. - Using the World Conservation Union Red List Categories and Criteria (IUCN, 2001), and considering the broad distribution of the species and the unlikelihood of any collection pressure, the species can tentatively be classified as Least Concern. However, few of the known populations are in protected areas and, similar to H. crucifera, loss of habitat is a real threat, as the dry or seasonal humid fields suitable for the species are also particularly suitable for agriculture.

Illustrations. - Werkhoven (1986: p.141, as H. obtusa); Renz (1992: fig. 2, based on the holotype).

Additional specimens examined. SURINAME. Wilhelmina Gebergte, $3^{\circ} 36^{\prime}-3^{\circ} 41^{\prime} \mathrm{N}, 56^{\circ} 30^{\prime}-56^{\circ} 34^{\prime} \mathrm{W}$, 9$14.5 \mathrm{~km}$ north of Lucie River, in east drainage of Oost River, 450 m, 21 Jul 1963 (fl), Maguire et al. 54275 (U, image seen); Wilhelmina Gebergte, 25 Jun 1926 (fl), Stahel 548 (AMES, U); Wilhelmina Gebergte, 1 Aug 1926 (fl), Stahel 576 (U, image seen).

FRENCH GUIANA. Mitaraka Sud, $54^{\circ} 31^{\prime} \mathrm{W}, 2^{\circ} 16^{\prime} \mathrm{N}$, 660 m, 24 Mar 2001 (fl), Sarthou 928 (P).

BRAZIL. Distrito Federal: Reserva Ecológica do IBGE, $15^{\circ} 46^{\prime} 41^{\prime \prime} \mathrm{S}, 47^{\circ} 53^{\prime} 07^{\prime \prime} \mathrm{W}, 1100 \mathrm{~m}, 15$ Jan 2001 (fl), Aparecida-da-Silva 4705 (CEN, IBGE); Parque Ecológico Norte, 19 Jan 1995 (fl), Batista 493 (CEN); area between the Parque Ecológico Norte and the Parque Nacional de Brasília, 22 Dec 1996 (fl), Batista 644 (CEN), 27 Dec 2001 (fl), Batista \& Bianchetti 1286 (CEN), 4 Jan 2005 (fl), Batista et al. 1555 (BHCB); Zoobotânico, 25 Jan 1967 (fl), Duarte 10242 (HB, RB); Brasília, Plano Piloto, 20 Feb 1967 (fr), Heringer 11358 (HB, NY); beginning of L 4, 18 Dec 1967 (fl), Heringer 11605 (HB, UB); Parque Ecológico Norte, 13 Jan 1995 (fl), Miranda 22 (CEN). Goiás: Cavalcante, entrance to Porto dos Paulistas, Curral Velho, km 6, 23 $27^{\prime} 43^{\prime \prime} \mathrm{S}$, $48^{\circ} 07^{\prime} 16^{\prime \prime} \mathrm{W}, 410$ m, 23 Jan 2001 (fl), Pereira-Silva et al. 4600 (CEN); Cavalcante, cross-road Vila Veneno-balsa do Rio São Félix-Cavalcante, km 32, 1340'53"S, 47 $05^{\prime}$ 46"W, 810 m, 21 Feb 2002 (fl), Pereira-Silva et al. 5946 (CEN). Minas Gerais: São Roque de Minas, Parque Nacional da Serra da Canastra, $37 \mathrm{~km}$ a partir da portaria principal de São Roque de Minas, em direção a Sacramento, 20 $0^{\circ} 10^{\prime} 49.4^{\prime \prime} \mathrm{S}, 46^{\circ} 39^{\prime} 44.8^{\prime \prime} \mathrm{W}, 1343 \mathrm{~m}, 12$ Dec 2007 (fl), Batista \& Carvalho 2335 (BHCB); São Roque de Minas, Parque Nacional da Serra da Canastra, $20^{\circ} 15^{\prime} 40.7^{\prime \prime} \mathrm{S}, 46^{\circ} 25^{\prime} 37.3^{\prime \prime} \mathrm{W}, 1370 \mathrm{~m}, 8$ Jan 2007 (fr), Batista et al. 1800 (BHCB), 20¹3'09.1"S, 46 27'50.4" W, 1423 m, 9 Jan 2007 (fr), Batista et al. 1811 (BHCB); São Roque de Minas, Parque Nacional da Serra da Canastra, 1 Jan 1999 (fl), Bertioli 12 (CEN). Paraná: Rio dos Papagaios, about 47-48 km W from Curitiba, km 551-552 in BR-376, 27 Oct 2001 (fl), Batista et al. 1263 (CEN); Balsa Nova, Tamanduá, 6 Nov 1966 (fl), Hatschbach 15064 (MBM). Rio Grande Do Sul: São José dos Ausentes, $14.6 \mathrm{~km}$ NE de São José dos Ausentes, 28 40'17.6"S, 4957'58.3"W, 1185 m, 2 Feb
2008 (fl), Batista 2493 (BHCB); 6 km after S. Francisco de Paula, Taimbezinho, 4 Jan 1978 (fl), Fleig 875 (ICN).

There are some differences among the material examined. In the plants from wet places from the Guianas, Minas Gerais, Paraná, and Rio Grande do Sul, the stem is shorter [(25-)36-41(-57) cm long vs. (42-) $60-108 \mathrm{~cm}$ long in specimens from dry places from Goiás and the Federal District], the leaves fewer $((3-) 4-5(-7)$ vs. 8-15), the largest leaves are concentrated at the lower half of the stem (vs. largest at the center), and the inflorescence have fewer flowers $((1-) 3-9(-11)$ vs. (8-)12-19 flowers). The habitat also varied greatly, as described above. However, despite the differences in habitat and habit and the broad geographical distribution, the general flower morphology is the same among the specimens examined and a separation at the moment does not seem justifiable. However, considering the differences above, it is possible that a more detailed morphological analysis based on broader sampling of more material from the Guianas and southern Brazil, combined with morphometrics, population genetics, molecular data, and reproductive biology studies may show that we are dealing here with more than one taxon. For the moment, $H$. montiswilhelminae can be distinguished from the other species in the $H$. crucifera var. crucifera aggregate by the medium-sized flowers (dorsal sepal (4-) $6-9(-12) \times(4-) 5.5-7(-9) \mathrm{mm})$, the lateral segments of the lip less than half the length of the median segment (lip lateral segments $0.2-0.4$ times as long as the median segment), the longer anther canals $(1.3-2 \mathrm{~mm}$ long vs. $0.4-1.3 \mathrm{~mm}$ long), the longer caudicles (2-2.5 m long vs. $0.5-1.5 \mathrm{~mm}$ long), the viscidia $1.8-2.8 \mathrm{~mm}$ apart from one another (vs. $0.2-1.5 \mathrm{~mm}$ apart from one another), and the taller rostellum midlobe (1.5-1.8 mm high $\times 0.6-1.3 \mathrm{~mm}$ high).

Renz (1992) included H. montiswilhelminae in the affinity of $H$. campos-porto $i$ Schltr., in our opinion a synonym of $H$. paranaensis Barb. Rodr., due to the short lateral segments of the petals and lip. However, $H$. paranaensis is very distinct from $H$. montiswilhelminae and is closely 

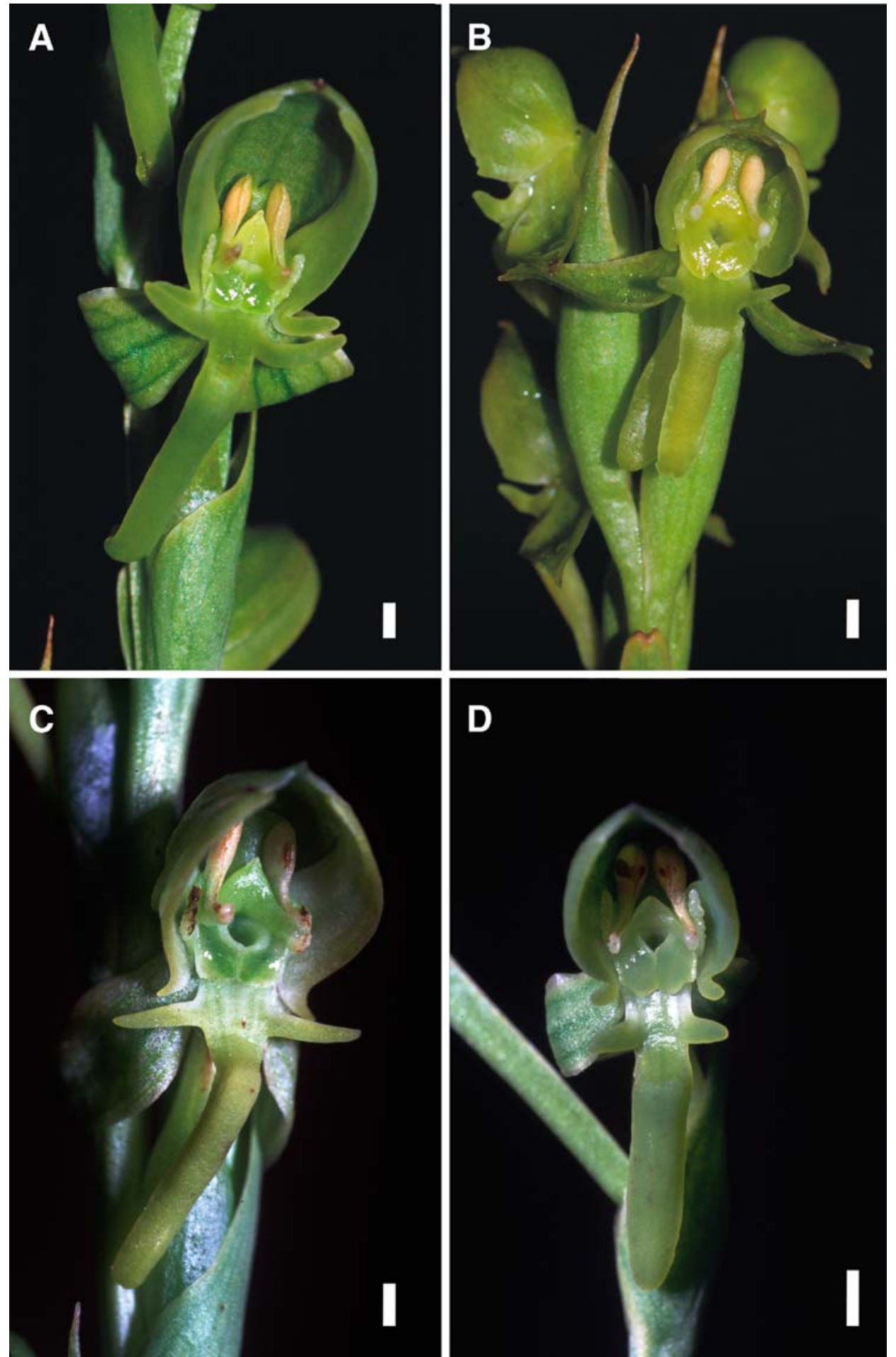

Fig. 8. Habenaria montiswilhelminae, flowers from live specimens. A. From Parque Nacional da Serra da Canastra, Minas Gerais, Brazil. B. From São José dos Ausentes, Rio Grande do Sul, Brazil. C. From Parque Ecológico Norte, Brasília, Federal District, Brazil. D. From Rio dos Papagaios, Paraná, Brazil. Scale bars=1 mm. 
related to $H$. secunda Lindl., $H$. gustaviedwallii Hoehne, H. araneiflora Barb. Rodr. $H$. achalensis Kraenzl., and H. brachyplectron Hoehne \& Schltr. The species in this group are characterized by broad, lanceolate leaves (up to $3 \mathrm{~cm}$ wide) that are not appressed to the stem, and by column morphology, with the inner margin of the stigma lobes having an acute projection at the apex, which turns upwards and touches the rostellum midlobe, dividing the entrance to the spur into two openings.

Habenaria spanophytica J. A. N. Batista \& L. B. Bianchetti, sp. nov. Type: Brazil. Distrito Federal: Samambaia, DF-280, em direção de Santo Antônio do Descoberto, dentro da área de Furnas, 7 Mar 1998 (fl), J. A. N. Batista 783 (holotype: CEN).

(Figs. 5, 6)

Habenariae cardiostigmaticae J. A. N. Bat. \& L. B. Bianch. similis, sed floribus minoribus (sepalo dorsali $(2.5-) 3 \times 2.5-3 \mathrm{~mm})$, segmentis lateralibus labelli brevioribus (3-3.5(-4.5) $\mathrm{mm}$ longis), aperatura inter stigmata calcar ducenti circulari, brachiis rostelli latioribus (ca. $0.4 \mathrm{~mm}$ latis), apicem versus convergentibus, viscidiis inter se prope continuis (ca. $0.2 \mathrm{~mm}$ ) differt.

Terrestrial herbs. Stem erect, (36-)48$88 \mathrm{~cm}$ long, including the inflorescence, (1-) 1.5-2 mm wide. Leaves 8-12, appressed to the stem, largest at the center of the stem, linear, narrow, 6-12×0.3-0.6 cm. Inflorescence (5-)8-13 cm long, few flowered, loose, somewhat secund; bracts ovate, caudate, 721 $\times 4-6.5 \mathrm{~mm}$, longer than the ovary + pedicel. Flowers (6-)10-15, small, greenish white; ovary + pedicel mostly parallel to the rachis, 9-12 mm long, slightly arched. Sepals light green, discretely mucronate, margin smooth, whitish; dorsal sepal concave, when flattened roundish, $(2.5-) 3 \times 2.5-3 \mathrm{~mm}$; lateral sepals obliquely lanceolate, deflexed, 3.5-4× 1.5-2 mm. Petals discretely bipartite, base whitish, turning light green towards the segments apices; posterior segment triangular to narrowly triangular, falcate, $2-3 \times 1 \mathrm{~mm}$, acute, free from the dorsal sepal; anterior segment reduced to a tooth-like projection, inserted at the base of the posterior segment, $0.5 \mathrm{~mm}$ long. Lip distinctly tripartite, base whitish, turning creamy white or light green towards the segments apices; undivided basal part short, $0.7 \times$
$1 \mathrm{~mm}$; lateral segments linear-filiform, 3-3.5 ( -4.5$) \mathrm{mm}$ long, the base usually perpendicular to the median segment; median segment linear, geniculate, $3(-4.5) \times 0.5 \mathrm{~mm}$. Spur pending, totally or partially covered by the bracts, clavate, shorter than the ovary + pedicel, 7$9 \mathrm{~mm}$ long, green, base $0.5-0.7 \mathrm{~mm}$ wide, apex 1-1.2 mm wide. Column erect, $2 \mathrm{~mm}$ high; connective emarginate, green; auricles fleshy, verrucose, whitish. Anther $1 \mathrm{~mm}$ high, canals 0.4-0.5 mm long; hemipollinarium separated; viscidia $0.3 \times 0.2 \mathrm{~mm}$, about $0.2 \mathrm{~mm}$ apart from one another; caudicles $0.5-0.6 \mathrm{~mm}$ long. Stigma lobes $1.5 \mathrm{~mm}$ long, green, receptive surface convex, turned forwards, closely parallel, free part $0.8-0.9 \times 0.6 \mathrm{~mm}$, apex truncate, inner margin thickened, space between the stigma lobes circular. Rostellum $1.5 \mathrm{~mm}$ long, green, midlobe triangular, fleshy, obtuse, completely placed between the anther loci, 0.6$0.7 \mathrm{~mm}$ long, $0.6 \mathrm{~mm}$ high, side-lobes converging towards the apex, $0.8-0.9 \times 0.4 \mathrm{~mm}$.

Etymology.-From the Greek spano (few) and phyton (plant), referring to the fact that the species is usually found as single individuals or in small groups.

Distribution.-The new species is known from the savanna-like cerrado vegetation of central Brazil, in the states of Goiás (Santo Antônio do Descoberto and Cavalcante), Minas Gerais (Paracatu and Carrancas), and the Federal District (several localities). In a checklist of the Orchidaceae of the Federal District the species was listed as Habenaria aff. aphylla 4 (Batista \& Bianchetti, 2003).

Habitat, ecology, and phenology.-The new species occurs in dry or seasonally humid grassy field (campo limpo) and grassherb-subshrub field vegetation (campo sujo), over shallow, dry or seasonally humid, sandy soil, very often on slopes with gravel and blocks of rocks over the surface, and sometimes over gray, dry, sandy-clay soil associated with murundus, at about $1000 \mathrm{~m}$. These soils can be superficially moist for brief periods during the rainy season, but never retain water for long periods and dry completely during the dry season. Other species such as Habenaria obtusa Lindl., H. lavrensis Hoehne, $H$. armata Rchb.f., H. brevidens Lindl. and H. secundiflora occur in the same habitat. Growth and flowering time occurs from the peak to the end of the rainy season, 
from late December to early April (Table I). Though brushfires are apparently not essential, they significantly enhance flowering. Six of the seven collections of the species made by the authors were done in previously burned areas. Although the species has been collected in several localities at different times, in the seven collections of the species made by the authors and three additional field records that lack voucher specimens, only a single individual of the species was found in each place. In many instances the surroundings of the collection site were exhaustively searched, but no additional plants could be found. All other herbarium collections of the species are also represented by single specimens, except the collections A.H. Salles et al. 4056, with two specimens in the sheet, and $H$. $S$. Irwin et al. 26225, with one duplicate. This is a remarkable characteristic, since other Habenaria species are usually found as large assemblages, suggesting that $H$. spanophytica occurs in very low density populations.

Conservation status.-According to the World Conservation Union Red List Categories and Criteria (IUCN, 2001) the species can tentatively be classified as Vulnerable VU (criteria B2ab(iii); D1).

Additional specimens examined. BRAZIL. Distrito Federal: Estação Ecológica Jardim Botânico de Brasília, $15^{\circ} 52^{\prime} \mathrm{S}, 47^{\circ} 51^{\prime} \mathrm{W}, 1025-1150 \mathrm{~m}, 17$ Mar 2005 (fl), Azevedo et al. 320 (HEPH); Setor de Mansões do Lago Norte, 14 Jan 1991 (fl), Batista 149 (CEN); Setor de Mansões do Lago Norte, 12 Feb 1997 (fl), Batista 676 (CEN); Chapada da Contagem, 31 Mar 1995 (fl), Batista \& Bianchetti 561 (CEN); Núcleo Bandeirante, Fazenda Sucupira, 28 Feb 1997 (fl), Batista et al. 730 (CEN); Fazenda da Embrapa, 17 Feb 1998 (fl), Batista et al. 766 (CEN); Chapada da Contagem, 4 Jan 1974, (fl) Heringer 13076 (UB); São Bartolomeu, 17 Mar 1980, Heringer et al. 3952 (IBGE); near Paranoazinho/Sobradinho stream, $15^{\circ} 38^{\prime} 59^{\prime \prime} \mathrm{S}, 47^{\circ} 51^{\prime} 05^{\prime \prime} \mathrm{W}, 15$ Mar 2005 (fl), Pastore et al. 1285 (CEN); Estação Ecológica Jardim Botânico de Brasília, 23 Mar 2006 (fl), Salles et al. 4056 (HEPH); NW of Sucupira farm, $15^{\circ} 5^{\prime} \mathrm{S}, 18^{\circ} 02^{\prime} \mathrm{W}, 30$ Dec 1998 (fl), Sampaio et al. 293 (CEN). Goiás: Santo Antônio do Descoberto, slopes about $2 \mathrm{~km}$ from the center of the town, 7 Mar 1998 (fl), Batista 775 (CEN); Cavalcante, 5 Apr 2003 (fl), Pastore \& Suganuma 579 (CEN). Minas Gerais: Carrancas, Serra das Bicas, $21^{\circ} 34^{\prime} 48.3^{\prime \prime} \mathrm{S}, 44^{\circ} 34^{\prime}$ 34.7"W, 1304 m, 15 Jan 2008 (fl), Batista et al. 2408 (BHCB); Serra da Anta, $12 \mathrm{~km} \mathrm{~N}$ of Paracatu, $950 \mathrm{~m}, 6$ Feb 1970, (fl) Irwin et al. 26225 (UB, NY).

As far as we could determine, this species was first collected in 1970 by H. S. Irwin in
Paracatu, Minas Gerais, and identified as $H$. aphylla by Pabst. In the morphology of the perianth, $H$. spanophytica is markedly similar to $H$. cardiostigmatica, having the appearance of a smaller form of the latter, and for a time we thought it belonged to a subspecific taxon of $H$. cardiostigmatica. However, H. spanophytica is distinct from $H$. cardiostigmatica not only by the consistently smaller flowers (dorsal sepal $(2.5-) 3 \times 2.5-3 \mathrm{~mm}$ vs. $3.5-4$ $(-4.5) \times 3(-4) \mathrm{mm}$ in $H$. cardiostigmatica) but primarily by the column structure (Table II). In the morphology of the column it differs not only from $H$. cardiostigmatica, but also from the other species related to $H$. crucifera var. crucifera. In $H$. spanophytica the rostellum side-lobes are broader (ca. $0.4 \mathrm{~mm}$ wide vs. $0.15-0.2 \mathrm{~mm}$ wide in $H$. cardiostigmatica) and converging towards the apex (vs. parallel in H. crucifera var. crucifera and in all the other related species). Although the apices of the rostellum side-lobes do not converge completely, the viscidia are closer to each other in $H$. spanophytica (ca. $0.2 \mathrm{~mm}$ ) than in the other species in the group $(0.7-2.8 \mathrm{~mm}$ apart from one another).

\section{Acknowledgments}

The authors thank the curators of AMES, BHCB, CEN, HB, HEPH, IBGE, ICN, MBM, MG, NY, OUPR, P, RB, SP, SPF, U, UB, and W for the loan of specimens, and for providing images or access to their collections, Gustavo Romero for material of $H$. montiswilhelminae, Simone C. Souza e Silva for preparing the illustrations, Tarciso Filgueiras for the Latin diagnoses, Maria Carolina A. Luque for revising the English, two anonymous reviewers, and Lawrence M. Kelly and the Latin editor of Brittonia for useful comments that helped improve the manuscript and FAPEMIG, Fundação $\mathrm{O}$ Boticário and $\mathrm{CNPq}$ for financial support.

\section{Literature Cited}

Barbosa Rodrigues, J. 1877. Genera et Species Orchidearum Novarum. I. C. \& H. Fleiuss, Rio de Janeiro.

Batista, J. A. N. \& L. B. Bianchetti. 2003. Lista Atualizada das Orchidaceae do Distrito Federal. Acta Botanica Brasilica 17: 183-201. 
\& 2006. The Brazilian Habenaria (Orchidaceae) with hairy segments. Sitientibus Série Ciências Biológicas 6: 9-23.

\& K. F. Pellizzaro. 2005. Orchidaceae da reserva ecológica do Guará, Distrito Federal, Brasil. Acta Botanica Brasilica 19: 221-232.

\& Z. J. G. Miranda. 2006. A revision of Habenaria section Macroceratitae (Orchidaceae) in Brazil. Brittonia 58: 10-41.

Cogniaux, A. 1893. Orchidaceae. Habenaria. In: C. F. P. Martius, A. G. Eichler \& I. Urban, (eds.), Flora Brasiliensis 3(4): 18-102, tabs. 3-18. F. Fleischer, München.

1906. Notes sur les orchidées du Brésil et des régions voisines. Bulletin de la Société Royale de Botanique de Belgique 43: 266-350.

Hoehne, F. C. 1937. Orchidaceae novae brasilienses. Habenaria. Botanische Jahrbücher für Systematik 68: $126-137$.

1940. Orchidaceas, Habenaria. In: F. C. Hoehne (ed.), Flora Brasilica 12(1): 52-254, tabs. 11-122. Secretaria da Agricultura, Indústria e Comércio de São Paulo, São Paulo.

IUCN. 2001. IUCN Red List Categories and Criteria, Version 3.1. IUCN Species Survival Commission. IUCN. Gland, Switzerland.

Kraenzlin, F. 1892. Beiträge zu einer monographie der gattung Habenaria Willd. Botanische Jahrbücher für Systematik 16: 52-223.

- 1901. Orchidacearum genera et species, Vol. I. Habenaria. Mayer and Müller, Berlin.
Kurzweil, H. \& A. Weber. 1992. Floral morphology of southern African Orchideae. II. Habenariinae. Nordic Journal of Botany 12: 39-61.

Pabst, G. F. J. 1971. Orquídeas do cerrado. Pp. 161163. III Simpósio sobre o cerrado. Edgard-Blücher, São Paulo.

\& F. Dungs. 1975. Orchidaceae Brasilienses, Vol. 1. Brucke-Verlag Kurt Schmersow, Hildesheim, Germany.

Pridgeon A. M., P. J. Cribb, M. W. Chase \& F. N. Rasmussen. 2001. Genera Orchidacearum, Vol. 2. Orchidoideae, part 1. Oxford University Press Inc, New York.

Ratter J. A., J. F. Ribeiro \& S. Bridgewater. 1997. The Brazilian cerrado vegetation and threats to its biodiversity. Annals of Botany 80: 223-230.

Reichenbach, H. G. 1881. VII-Novitiae Orchidaceae Warmingianae. Otia Botanica Hamburgensia 2: 48-65.

Renz, J. 1992. The genus Habenaria (Orchidaceae) in the Guianas. Candollea 47: 483-512.

Stace, C. A. 1989. Plant taxonomy and biosystematics, $2^{\text {nd }}$ ed. Edward Arnold, Hodder and Stoughton Limited.

Sprunger, S. (ed.). 1996. João Barbosa Rodrigues Iconographie des orchidées du Brésil, Vol. 1. Illustrations. Friedrich Reinhardt Verlag, Basle, Switzerland.

Warming, E. 1884. Symbolae ad floram Brasiliae centralis cognoscendam. Part. 30. Orchideae 2. Videnskabelige Meddelelser Fra den naturhistoriske forening i Kjobenhavn 5-8: 86-99.

Werkhoven, M. C. M. 1986. Orchids of Suriname. Vaco Uitgeversmaatschappij, Paramaribo. 